\title{
Astrobiology
}

Astrobiology Manuscript Central: http://mc.manuscriptcentral.com/astrobiology

\section{VOLCANO-ICE INTERACTION AS A MICROBIAL HABITAT ON EARTH AND MARS}

\begin{tabular}{|r|l|}
\hline Journal: & Astrobiology \\
\hline Manuscript ID: & AST-2010-0550.R2 \\
\hline Manuscript Type: & Reviews \\
\hline $\begin{array}{r}\text { Date Submitted by the } \\
\text { Author: }\end{array}$ & 15-Apr-2011 \\
\hline Complete List of Authors: & $\begin{array}{l}\text { Cousins, Claire; Birkbeck College, University of London, Earth and } \\
\text { Planetary Sciences } \\
\text { Crawford, I.A. }\end{array}$ \\
\hline Keyword: & Volcanism, Mars, Ice, Habitability, Hydrothermal Systems \\
\hline \multicolumn{2}{|c}{} \\
\hline
\end{tabular}

\section{SCHOLARONE \\ Manuscripts}


1 VOLCANO-ICE INTERACTION AS A MICROBIAL HABITAT ON

2 EARTH AND MARS

3

4 Claire R Cousins ${ }^{1,2} \&$ Ian A Crawford ${ }^{1,2}$

5

$6 \quad{ }^{1}$ Department of Earth and Planetary Sciences, Birkbeck College, University of 7 London, WC1E 7HX.

$8{ }^{2}$ Centre for Planetary Sciences at UCL/Birkbeck, Gower Street, London, WC1E $96 \mathrm{BT}$.

10

\section{Abstract}

12 Volcano-ice interaction has been a widespread geologic process on Earth that

13 continues to occur to the present day. The interaction between volcanic activity

14 and ice can generate substantial quantities of liquid water, together with steep

15 thermal and geochemical gradients typical of hydrothermal systems.

16 Environments available for microbial colonization within glaciovolcanic systems

17 are wide-ranging and include the basaltic lava edifice, subglacial caldera

18 meltwater lakes, glacier caves, and subsurface hydrothermal systems. There is

19 widespread evidence of putative volcano - ice interaction on Mars throughout its

20 history and at a range of latitudes. Therefore, it is possible that life on Mars may

21 have exploited these habitats, much in the same way as has been observed on 
22 Earth. The sedimentary and mineralogical deposits resulting from volcano-ice

23 interaction have the potential to preserve evidence of any indigenous microbial

24 populations. These include jökulhlaup (subglacial outflow) sedimentary deposits,

25 hydrothermal mineral deposits, basaltic lava flows, and subglacial lacustrine

26 deposits. Here, we briefly review the evidence for volcano-ice interactions on

27 Mars and discuss the geomicrobiology of volcano-ice habitats on Earth. In

28 addition, we explore the potential for the detection of these environments on Mars

29 and any biosignatures these deposits may contain.

\section{1. Introduction}

32 The detection of extraterrestrial life has become a major goal in modern space

33 exploration, with Mars in particular being recognized as an appropriate target. The

34 search for life on Mars during the past few decades has been significantly aided

35 by research into life within martian analogue environments on Earth (e.g.,

36 Cavicchioli 2002). Environments that have received considerable attention as

37 proxies for past or present martian habitats include the Antarctic Dry Valleys

38 (Wierzchos et al., 2005; Walker \& Pace 2007), the Atacama Desert (Navarro-

39 Gonzalez et al., 2003), evaporite environments (Rothschild 1990; Edwards et al.,

40 2006), and permafrost (Gilichinsky et al., 2007). These environments have shown

41 an array of resilient microbial communities that thrive under harsh environmental 
42 conditions and provide a framework from which to develop life-detection 43 strategies for Mars.

45 The martian crust is predominantly igneous in nature and ranges from basaltic to 46 andesitic in composition (McSween et al., 2009). Therefore, it is imperative to 47 understand martian volcanic environments in terms of their habitability and 48 potential for microbial colonisation. In particular, where volcanism interacts with 49 liquid water, there is the potential to support life, as seen on Earth (e.g., Boston et 50 al., 1992). Liquid water is unstable at the martian surface today and has been for a

51 considerable part of its history. Water currently exists as a largely continuous

52 global cryosphere within, or below, the regolith (Clifford 1993; Kuzmin 2005;

53 Clifford 2010), with the largest known reservoirs of water today frozen at the 54 poles (Carr 1987; Jakosky \& Phillips 2001; Hvidberg 2005; Clifford 2010) and 55 within a latitude dependent mantle (Levy et al. 2010). Differences in localized 56 lithospheric heat flow and crustal thermal properties are likely to result in spatial 57 variation in the cryosphere thickness (Clifford 2010). This cryosphere, coupled 58 with volcanic activity, has the potential to produce several kinds of environments 59 for life on Mars with a wide range of thermal and chemical conditions, 60 particularly through the generation of hydrothermal systems (Chapman et al., 61 2000; Head \& Wilson 2002; Schulze-Makuch et al., 2007). It has previously been 62 suggested that where regions of volcano - ice interactions are found, suitable sites 
63 may exist to search for evidence of martian life (Boston et al., 1992; Farmer 1996;

64 Hovius et al., 2008; Gulick 1998; Payne \& Farmer 2001). Here, we review

65 glaciovolcanism on both Earth and Mars within the context of assessing the range

66 of microbial habitats that exist through volcano - ice interaction, as well as the

67 potential for biosignature preservation within these environments.

69 2. Glaciovolcanism on Earth

70 The interaction between volcanism and ice on Earth is on-going and widespread.

71 Glaciovolcanism specifically describes any interaction between volcanism and

72 ice, including glaciers, snow, firn (recrystallised snow), and ground ice (Smellie

73 2006; 2007). Chapman et al., (2000) described three types of volcano - ice

74 interaction: "Type 1" is an alpine interaction with volcano summit snow and

75 valley glaciers; "Type 2" a continental ice sheet/glacier interaction; and "Type 3"

76 involves the interaction with lava and surface ground ice. Type 2 includes

77 subglacial volcanism in its true definition, which is specific to volcanic eruptions

78 beneath thick glaciers and ice sheets (Smellie 2006), and on Earth subglacial

79 volcanism is a common feature of volcanically active, high latitude terrains.

80 Examples of widespread subglacial volcanism today include those found in

81 Iceland (Gudmundsson et al. 1997; Bourgeois et al., 1998), British Columbia

82 (Edwards et al., 2002), and Antarctica (Smellie \& Skilling 1994; Smellie et al.,

83 2008). In Iceland in particular, many volcanoes are situated beneath the 
84 Vatnajokull ice cap (Chapman et al,. 2000), some of which maintain subglacial

85 meltwater lakes (see Section 4.1). Geomorphological products indicative of 86 basaltic subglacial volcanism include tuyas (Figure 1a) and moberg/hyaloclastite

87 ridges. Tuyas form as a result of central vent eruptions into an overlying thick ice 88 sheet (Bourgeois et al., 1998), while hyaloclastite ridges result from a series of

89 fissure eruptions beneath ice, which form long ridges that follow the strike of the

90 rift. These eruptive features display a distinctive elevated topography in contrast

91 to the surrounding terrain due to the restrictive role of the ice into which the lava

92 was erupted, preventing the lateral flow of lava away from the eruptive center.

93 Subsequent retreat of ice reveals these distinctive volcanic landforms (Figures 1a 94 and $b)$.

95

96 During an eruption, conductive heat flow melts the surrounding ice, while the low

97 temperatures of the ice begin to solidify the magma under high water pressure, 98 typically forming effusive pillow lava formations (Jakobsson \& Gudmundsson 99 2008). Convection also plays a large role in the transfer of heat from the magma 100 body to the overlying ice (Höskuldsson \& Sparks 1997), which produces a 101 growing zone of meltwater. Over time, a subglacial edifice can grow within this 102 meltwater "lens"”(Figure 2a), broadly consisting initially of pillow basalts (Figure $103 \mathrm{1b}$ ), and then hyaloclastite beds and palagonite tuffs as the confining pressure 104 reduces and the eruption becomes more explosive (Smellie \& Skilling 1994; 
105 Jakobsson \& Gudmundsson 2008). If the edifice becomes large enough to break

106 through the ice, a cap rock of horizontal subaerial lava may be deposited (Figure 107 2b).

108

109 When the eruption is smaller, perhaps the result of a fissure, entirely subglacial

110 hyaloclastite ridges or pillow mounds (Figure 1b) will form. These edifices will

111 remain beneath the glacier until exposed and eroded. As magma flow diminishes,

112 the growth of the lava edifice ceases, but the overlying ice continues to melt due

113 to the convective transfer of heat through the liquid water interface between the

114 magma and the ice (Head \& Wilson 2002). Figure 2 summarizes these processes

115 and associated environments. Additionally, subglacial hydrothermal systems may

116 continually melt the base of the glacier, which would sustain a subglacial caldera

117 lake between eruptions (Björnsson 2002). Such caldera lakes, and meltwater

118 generated during an eruption, are typically catastrophically released as jökulhaups

119 (Roberts 2005; Figure 2c). In the case of Eyjafjallajökull - the Icelandic volcano

120 that erupted in April 2010 - the eruption was initially subglacial beneath the small

121 ice cap, but after a few hours this changed to phreatomagmatic activity coupled

122 with meltwater discharge, with the lava eventually emerging from the eruption

123 site $\sim 1$ week after the initial eruption, having melted through the ice

124 (Gudmundsson et al., 2010).

125 


\section{3. Glaciovolcanism on Mars}

\subsection{Volcanism and the cryosphere}

128 Volcanism on Mars has occurred throughout its history (Fassett \& Head 2010);

129 evidence of volcanic activity (e.g., lava flows) spans from the Noachian right up

130 to the very recent Amazonian (Hartmann, 2005; Werner 2009). Indeed, at specific

131 localities such as Olympus Mons and Hectes Tholes, the ages of lava flows span

$132 \sim 80 \%$ of martian history (Neukum et al. 2004). Evidence of past glaciation is also

133 widespread, both spatially and temporally, with evidence of large polar ice caps in

134 the Hesperian and low-latitude Amazonian glaciations (Kargel \& Strom 1992;

135 Carr \& Head 2010). Likewise, the subsurface cryosphere has been a long-lived

136 and widely distributed source of ice (Clifford et al., 2010). Therefore, it is highly

137 probable that these major processes have interacted in the past (Chapman et al.,

138 2000; Head \& Wilson 2002) and may even continue to do so today deep within

139 the subsurface (Schulze-Makuch et al., 2007). As a result, volcano - ice

140 interaction may represent an environment that has persisted over a significant part

141 of martian history.

142

\section{$143 \quad 3.2$ Glaciovolcanism through Martian history}

144 The processes and occurrences of volcano - ice interactions on Mars have been 145 reviewed and discussed in depth by Chapman et al., (2000), Head \& Wilson 146 (2002; 2007), and Chapman (2003), and involve the emplacement of sills, dykes, 
147 lava flows, and large magma bodies into cryospheric permafrost or into an

148 existing ice cap. It has been suggested that glaciovolcanic activity has occurred

149 throughout the history of Mars (Head \& Wilson 2007; Chapman et al., 2000), and

150 there are many topographic features on Mars that have been interpreted as

151 products of volcano-ice interaction (Table 1, Figure 3). Allen (1979) identified

152 many putative subglacial volcanoes in both the northern plains and near the south

153 polar cap of Mars. Since then, more candidate subglacial volcanoes and regions of

154 volcano - ice interaction have been identified (examples summarized in Table 1

155 and their locations shown in Figure 3). These include flat topped tuyas/edifices

156 (Figure 5a; Ghatan \& Head 2002; Head \& Wilson 2007), lava ridges/dykes

157 (Figure 5b; Ghatan et al., 2003; Head \& Wilson 2007), pseudocraters (Figure 5f;

158 Lanagan et al. 2001; Fagents \& Thordarson 2007), major outflow channels typical

159 of glacial outburst floods caused by geothermally melted ice (jökulhlaups)

160 (Figures 5c, d, Figure 5b); Head \& Wilson 2002), and marginal drainage channels

161 (Head \& Wilson 2007). Jökulhlaups in particular have been proposed as an

162 explanation for some of the numerous outflow channels and valleys (Figures $5 \mathrm{~d} \&$

163 6b) apparently carved by liquid water (Carr \& Head 2003; Fassett \& Head 2007;

164 Baker 2001; Rice and Edgett 1997), with the large flood deposits and catastrophic

165 outwash plains identified on Mars as comparable to those generated by Icelandic

166 jökulhlaups (Hovius et al., 2008; Fishbaugh \& Head 2002). As illustrated by

167 Gulick (1998), much of the fluvial erosion on Mars is spatially and temporally 
168 related to volcanic activity. Baker (2001) and Burr et al. (2002) also observed that

169 catastrophic flood channels and volcanic lava flows are closely associated in the

170 Cerberus Rupes and Marte Vallis region. This further demonstrates the potential

171 importance of volcanism in the generation of liquid water available to life on 172 Mars.

173

174 It has been widely suggested that Noachian Mars (Figure 4) represented a warmer, 175 and perhaps more clement, period of martian history (e.g., Craddock \& Howard 176 2002; Chevrier et al., 2007; McKeown et al., 2009) that was followed by a change 177 to acidic, cold, and desiccating surface conditions at the beginning of the

178 Hesperian (Bibring et al. 2006). If true, and if life did indeed evolve in the very 179 early history of Mars, glaciovolcanic environments during the Hesperian and 180 Amazonian may have provided a subsurface refuge as an alternative to the 181 increasingly hostile surface conditions. Here, both Hesperian and Amazonian 182 examples of glaciovolcanism are described (see Table 1, and Figures 3, 5, and 6 183 for localitions and images).

185 At the Hesperian volcano Ceraunius Tholus (see map in Figure 3), there is clear 186 evidence for drainage valleys and a depositional fan originating from the caldera 187 rim (Figure 6d). The geometry of this rim is such that it would favor the 188 accumulation of meltwater sourced from the geothermal melting of snowpack at 
189 the summit of the volcano (Fassett \& Head 2007). Likewise, the south polar Dorsa

190 Argentea Formation (Figure 6a) has been interpreted several times to be an area of

191 multiple subglacial volcanic eruptions with associated meltwater accumulation

192 and drainage (Ghatan \& Head 2002; 2003; Milkovich et al. 2002; Dickson \&

193 Head 2006). This Hesperian-aged, volatile-rich deposit displays evidence for

194 significant melting (e.g., channels, eskers, Figure 6c), with valleys interpreted to

195 have been outflow regions that drained significant quantities of meltwater from a

196 thinning southern circumpolar ice sheet, induced by volcanic activity (Ghatan \&

197 Head 2004; Milkovich et al. 2002; Head \& Pratt 2001). Finally, interior layered

198 deposits (ILDs; Figure 5e) within the late-Hesperian Juventae Chasma have been

199 interpreted by some workers to be the result of sub-ice volcanism (Chapman \&

200 Tanaka 2001; Chapman 2003). These, and other nearby "light-toned layered

201 deposits" (LLDs) have been found to contain a number of hydrated minerals,

202 including monohydrated sulphates, opal, and ferric sulphates, along with mafic

203 minerals that include pyroxenes and olivine (Bishop et al. 2009). It has been

204 hypothesized that hydrothermal processes may have been involved in the

205 deposition of opal, with subice volcanism providing the necessary heat source

206 (Bishop et al. 2009).

207

208 More recently, possible subglacially emplaced dyke swarms (Figure 5b), and 209 potentially also moberg ridges, have been identified between the Elysium Rise 
210 and Utopia basin (Pedersen et al., 2010), while Levy et al. (2010) identified

211 features at Galaxias Fossae that bear a striking similarity to volcanogenic glacial

212 cauldrons on Earth (Figure $5 \mathrm{~g}$ ). The martian cryosphere has of course changed

213 significantly over time, due to a combination of local and global climate change

214 (Baker et al., 1991; Clifford et al., 2010), and effects of obliquity variations

215 (Forget et al., 2006). Evidence for Amazonian glaciation at mid - low latitudes

216 due to high martian obliquity is now well recognized (Head et al., 2003; Neukum

217 et al., 2004; Schorghofer 2007; Fassett et al., 2010). As such, glaciovolcanic

218 products have been identified in the equatorial regions of these terrains (Chapman

219 2003; Leask et al., 2006; Kadish et al., 2008) as well as in more polar latitudes. In

220 particular, both glaciation and volcanism are thought to have occurred as recently

221 as the late Amazonian (Dickson et al. 2011), and Head et al. (2003) identified

222 deposits consistent with a possible martian ice-age $2.1-0.4$ million years ago. At

223 Olympus Mons, Neukum et al. (2004) found the youngest lava flows to be <30Ma

224 in age and identified multiple episodes of volcanic and glacial activity, with

225 associated hydrothermal water release caused by the melting of ground ice by 226 magma intrusion.

228 4. Glaciovolcanic microbial habitats

229 The importance of subglacial volcanism for martian exobiology lies in the 230 observation that basaltic subglacial eruptions on Earth generate large volumes of 
231 liquid water that can be stored and transported beneath the overlying glacier

232 (Wilson \& Head 2002), and that many of the environments that result from such

233 volcanism exist within the subsurface. In particular, the interaction between

234 geothermal heat flow and an overlying cryosphere or ice cap is highly conducive

235 to the generation of hydrothermal systems (Schulze-Makuch et al., 2007), both

236 during and between eruptions (Björnsson 2002; Wilson \& Head 2007). Subglacial

237 volcanic habitats range from the overlying cryosphere to deep within the lava

238 edifice, and these are discussed here individually. Examples of the microbiota and

239 physicochemical characteristics of selected environments are also provided in

240 Table 2.

241

242 4.1. Subglacial caldera lakes

243 During and between subglacial eruptions, meltwater can be confined as a

244 subglacial caldera lake (Gudmundsson et al., 1997). Such caldera lakes exist in

245 Iceland (Björnsson 2002; Johannesson et al., 2007) and have been inferred to have

246 existed on Mars (Fassett \& Head 2007). The lakes in Iceland are inhabited by a

247 specialized population of psycrotolerant and chemotrophic bacteria (Table 2) in

248 the lake water and volcanic sediments that lie at the bottom of the lake (Gaidos et

249 al., 2004; 2008). One of these caldera lakes is characterized by a largely anoxic

250 mixture of glacial meltwater and sulphidic geothermal fluid (Gaidos et al. 2008).

251 A bacterial community based on acetogenesis, sulphate reduction, sulphide 
252 oxidation, and potentially methanogenesis is tentatively inferred, with 253 acetogenesis in particular hypothesized to be an important input of carbon into 254 this ecosystem (Gaidos et al. 2008). These caldera lakes can exist as a habitable 255 environment until catastrophically drained as a jökulhlaup and can be highly 256 dependant upon the underlying geometry of the volcanic edifice and overlying ice 257 (Gudmundsson et al., 1997). At Grimsvotn, the topography is such that meltwater 258 can accumulate and form a relatively stable lake until either there is an eruption 259 event or the ice damming the lake is breached (Björnsson 2002). Conversely at

260 Gjálp, continual drainage of $\sim 20^{\circ} \mathrm{C}$ temperature meltwater away from the eruption 261 site has been observed, with no subsequent ponding of water (Gudmundsson et 262 al., 2004; Jakobsson \& Gudmundsson 2008). These subglacial caldera lakes 263 represent one of the most potentially exciting environments within the volcano 264 ice system.

266 4.2. Subglacial lava edifices

267 Basalt, combined with localized areas of hydrothermal activity, has the potential 268 to be colonized by a chemosynthetic-based ecosystem on Mars (Boston et al., 269 1992). Mild hydrothermal activity within the volcanic edifice is thought to occur 270 in the several years following an eruption, based on observations of modern 271 subglacial eruptions in Iceland, such as Gjálp (Jakobsson \& Gudmundsson 2008). 272 Basalt is the most abundant geological substrate on Earth and Mars, and as such a 
273 significant amount of work has focused on exploring life that inhabits this

274 environment on Earth. Terrestrial basaltic habitats exist predominantly at, and

275 below, the sea floor, within the continental subsurface environments (e.g.,

276 aquifers), and as subaerial substrates (e.g., lava flows). Oceanic basaltic lava

277 flows in particular have been the subject of much investigation regarding their

278 microbiota over the past few decades. Fresh basalt erupted from mid-ocean ridge

279 systems is widely found to be colonized and altered by a range of bacterial and

280 archaeal chemosynthetic microbial communities. These can exploit the redox

281 gradients between reduced species and oxygenated sea-water, such as for Fe

282 oxidation (Edwards et al. 2003), as well as employ anaerobic pathways such as

283 methanogenesis, $\mathrm{S}^{0}$ reduction, sulphate reduction, and Fe reduction (Martin et al.

284 2008). Additionally, basaltic habitats within the terrestrial deep subsurface have

285 been of interest in terms of understanding subsurface ecosystems on Earth and

286 potentially on other planets, such as Mars (Stevens \& McKinley 1995; McKinley

287 \& Stevens 2000).

289 Volcanic edifices that currently exist beneath glaciers on Earth are directly 290 analogous to those that may have existed on Mars, but these environments are yet 291 to be explored regarding their microbiota. Those edifices that have been exposed 292 by glacial retreat have been found to host surprisingly diverse bacterial 293 communities. Recent work by Cockell et al., (2009a; 2009b), and Herrera et al., 
294 (2009) demonstrated the exploitation of subglacially erupted basaltic

295 hyaloclastites as a favorable volcanic habitat for crypto- and chasmoendolithic life

296 (see Table 2). This widespread utilization of basaltic environments on Earth

297 suggests that any potential biological colonization of subglacial volcanic systems

298 on Mars is likely to exploit the basaltic volcanic edifice as both a physical

299 substrate on which to attach and as a source of energy.

300

301 4.3. Cryospheric hydrothermal environments

302 Glaciers and permafrost on Earth are known to contain a diverse array of 303 psycrophillic and mesophillic life, particularly in basal ice (Table 2) or at the ice304 rock boundary (Priscu \& Christner 2004). Such communities could be 305 incorporated into temporary hydrothermal systems within the cryosphere. Martian 306 permafrost also has the potential to provide a habitable environment through the 307 interaction with elevated geothermal heat and the subsequent production of 308 meltwater. This is especially true where magma intrusions have a large surface 309 area/volume ratio, such as dykes and sills (Head \& Wilson 2002). Although no 310 present-day geothermal anomalies have been detected (Christensen et al. 2003),

311 the widespread evidence of significant volcanism and endogenic hydrothermal 312 activity suggests higher heat flow in the past (Schulze-Makuch et al. 2007). 313 McKenzie \& Nimmo (1999) calculated that a $16 \mathrm{~km}$ wide dyke intrusion into a 5 $314 \mathrm{~km}$ thick permafrost layer (ice fraction 0.2 by volume) would produce a 
315 subsurface lens of meltwater with a volume of $6.5 \mathrm{~km}^{3}$ for each kilometer length 316 of the dyke, and that such a meltwater zone would not start to refreeze until $\sim 8$

317 Ma after the dyke intrusion. Similarly, Travis et al. (2003) showed that 318 hydrothermal circulation can occur on Mars with sufficient geothermal heat

319 interacting with the overlying permafrost and also suggested that these upwelling

320 hydrothermal plumes could provide a suitable environment for chemosynthetic

321 life (Travis et al., 2004). Such permafrost hydrothermal systems would remain

322 within the subsurface, except for directly above magma intrusions or where

323 springs breach the surface (e.g., along fractures) (Chapman et al., 2000).

325 In addition, where a volcanic eruption has taken place beneath a glacier, there is

326 the potential for glacier caves to form within the ice itself, carved by the drainage

327 of hydrothermal fluids and meltwater. Little is known about the processes that 328 occur at the glacier base in volcano - ice settings, including the formation of these 329 glacial caves (Tuffen et al., 2002). Some of the best described caves are those at 330 Mount Rainier, where fumarole interaction with overlying firn and snow produced 331 caves over $1.5 \mathrm{~km}$ in length (Kiver \& Mumma 1971; Zimbelman et al., 2000).

332 Some of these caves were observed to be steam-filled through fumarolic activity

333 (Zimbelman et al., 2000), and meltwater was seen to drip continuously from cave 334 walls and ceilings (Kiver \& Mumma 1971). A small crater lake was also observed 335 within part of the cave system (Kiver \& Steele 1972). Glacier caves associated 
336 with subglacial volcanism also exist in Iceland (Figure 1d), and similar "ice

337 towers" have been identified at Mt. Erebus, in Antarctica (Hoffman \& Kyle

338 2003). These caves provide an ice, and water-rich subsurface environment,

339 potentially coupled with fumarolic input. Such environments would be highly

340 favorable for microbial colonization on Mars, and exploration into the

341 microbiology of those on Earth would shed significant light on this issue.

342

343 Finally, high localized geothermal heat flow can also melt the overlying glacial

344 ice or permafrost in isolated areas at the surface and form glacial springs (Figure

345 1f) and intraglacial meltwater lakes (Figure 1e) that interact with surface

346 fumaroles. Such volcanically driven environments exist in the Atacama (Costello

347 et al., 2009), Antarctica (Soo et al., 2009), and Iceland (Olafsson et al., 2000), and

348 often produce "islands" of biodiversity within an otherwise highly hostile

349 environment (Costello et al., 2009). Martian hydrothermal systems have been

350 suggested many times as an environment suitable for microbial life (e.g., Rathbun

351 \& Squyres 2002; Varnes et al., 2003; Pope et al., 2006), and those generated

352 through volcano - ice interaction are no exception.

353

$354 \quad$ 5. Biosignature preservation

355 The generation of widely varying environments through volcano - ice interaction

356 results in a diverse range of deposits within the geological record. Evidence for 
357 putative glaciovolcanism appears to span almost the entirety of martian geological

358 history (Table 1, Figure 4), although the majority of examples are from Hesperian

359 and Amazonian terrains where geomorphological features are best preserved.

360 Those features that are consistent with the generation and ponding of meltwater

361 are perhaps the most optimum targets, regardless of their age. In particular,

362 deposits representative of environments analogous to the subglacial caldera lakes

363 seen in Iceland (such as jökulhlaup deposits) could be primary targets. These and

364 other products of volcano - ice interaction, including basaltic lavas and

365 hydrothermal mineral deposits, are discussed below regarding their biosignature

366 preservation potential.

367

368 5.1 Jökulhlaup deposits

369 Evidence for life in volcano - ice systems could be recorded via the presence of

370 biomolecules within subglacially erupted basalt and jökulhlaup deposits. Data

371 from the orbiting hyperspectrometers CRISM and OMEGA show the presence of

372 phyllosilicate minerals at the martian surface, with smectite clay minerals such as

373 montmorillonite and nontronite having been identified (e.g., Poulet et al., 2009). It

374 has been proposed that clay-rich deposits may be suitable sites of organic

375 preservation on Mars (Ehlmann et al., 2008). Such minerals are ubiquitous among

376 subglacially erupted basaltic lavas, due to the widespread breakdown of volcanic

377 glass to palagonite and smectite clays through contact with liquid water (Stroncik 
378 \& Schmincke 2002). Phyllosilicate detection on Mars to date has been restricted

379 to a few Noachian terrains such as Nili Fossae (Mustard et al. 2009) and Mawrth

380 Valles (Michalski \& Noe Dobrea 2007). It has yet been found to coincide with

381 putative volcano - ice geomorphological features, although a recent study by

382 Martinez-Alonso et al. (2011) tentatively indicates $\mathrm{Mg}$-smectite clays to be

383 associated with mesas interpreted to be subglacial tuyas. Volcano - ice landforms

384 therefore could be considered suitable spectroscopic targets for future

385 investigation. If such deposits coincide with volcano - ice interaction terrains on

386 Mars, these could be prime geological formations to search for evidence of life.

387 Indeed, Warner \& Farmer (2010) used visible-near infrared and shortwave

388 infrared remote sensing to spectrally identify low-temperature hydrothermal

389 mineralogical assemblages within Jökulhlaup deposits in south Iceland. As

390 suggested by these authors, such "mineralogical fingerprints" can be used to

391 identify potentially past habitable conditions within a subglacial volcanic system

392 and are therefore ideal astrobiological targets. An example of such a target

393 includes the drainage valleys and deposits at the edge of the Dorsa Argentea

394 Formation (DAF; Figure 6a). Here, sinuous channels lead away from the bases

395 and margins of candidate subglacial volcanoes (Ghatan \& Head 2002; Head \&

396 Wilson 2007). This terrain is thought to be formed much in the same way as

397 Icelandic jökulhlaup deposits, where drainage channels leading away from the 
398 DAF are interpreted to represent volcanism-induced subglacial meltwater release

399 (Ghatan \& Head 2004).

400

$401 \quad 5.2$ Hydrothermal deposits

402 Hydrothermal systems on Earth are noted for their ability to preserve detailed 403 microbial fossils, particularly within silica (Preston et al., 2008) and carbonate 404 (Allen et al., 2000) systems. Indeed, silica deposits of possible fumarolic or 405 hydrothermal origin have been identified by the MER Spirit landing site (Squyres 406 et al. 2008). However, such preservation is dependant upon the deposition of 407 mineralized or solute-rich fluids and the subsequent precipitation of the mineral 408 phases and preservation through fossilization of the in situ microbial community. 409 There are examples where concentrated mineral deposits form within, or as a 410 direct result of, volcano - ice interaction. At the Bockfjord volcanic complex in 411 north-west Spitsbergen (Norway), the subglacially erupted volcanoes Sigurdfjell 412 and Sverrefjell contain basaltic lavas with hydrothermal carbonate cement 413 deposits (Blake et al., 2010). These carbonates demonstrate a potential 414 mechanism for the preservation of microfossils and organic biosignatures within a 415 volcano - ice system on Mars. Additionally, subglacially erupted pillow lavas in 416 central Iceland (Figure 1b) have been found to contain gypsum deposits within the 417 lava vesicles, most likely precipitated during hydrothermal circulation within the 418 subglacial edifice following eruption (Storrie-Lombardi et al. 2009). Such 
419 deposits, if found on Mars, would suggest a once-habitable subsurface

420 hydrothermal environment that may have preserved signatures of life.

421

422 Alternatively, where subsurface silica-charged hot spring fluids are frozen through

423 eruption into a sub-zero environment, cryogenic opal-a is precipitated between ice 424 crystals, which produces distinctive cryogenic particle morphologies (Channing \& 425 Butler 2007). As suggested by Channing \& Butler (2007), this precipitation may 426 fossilize any microorganisms present within the hot-spring fluid, which are 427 partitioned out of the growing ice crystals and into the surrounding liquid vein 428 network along with the silica (Mader et al., 2006; Channing \& Butler 2007).

430 Finally, the subglacial volcano Kverkfjöll in Iceland is associated with several 431 hydrothermal systems (Cousins et al., 2010). One of these - the hot spring 432 Hveragil - has thick deposits of calcite along the floor of the gully that the hot 433 spring flows along (Ólafsson et al., 2000) and, as with many hot spring mineral 434 deposits, is likely to contain biosignatures such as microfossils, organics, or both. 435 Little is known regarding the preservation of biosignatures within such systems 436 generated by volcano - ice interaction, and this represents a significant area of 437 research with direct implications for the search for life on Mars. One significant 438 drawback, however, is the often small-scale and highly localized nature of such 
439 mineral deposits (e.g., to an isolated spring), which could potentially hinder their

440 discovery.

441

$442 \quad 5.3$ Subglacially erupted lavas

443 Glassy basaltic lavas on Earth often contain intricate tubular and pitted structures,

444 which have been widely interpreted to be formed by the activities of euendolithic

445 microbes at the glass - palagonite interface (Furnes et al., 2007 and references

446 therein; McLoughlin et al., 2009). Typically, $80-90 \%$ of hyaloclastite is glass

447 (Jakobsson \& Gudmundsson 2008), which leads to the possibility for the

448 significant production of microbial bioalteration textures so commonly seen in

449 submarine glassy lavas (McLoughlin et al., 2009). It has been previously

450 suggested that these bioalteration textures would make suitable biosignatures

451 when looking for life on Mars (Banerjee et al. 2006; McLoughlin et al., 2007),

452 particularly when they are preserved by minerals such as zeolites and titanite 453 infilling tubular textures (Furnes et al., 2004; Izawa et al., 2010). However, while

454 these putative biosignatures appear to be ubiquitous in lavas within an oceanic 455 setting, an abundance of such textures is yet to be found in basalt of a subglacial 456 origin, despite sharing the same glassy lithologies (pillow lavas and 457 hyaloclastites). A recent study by Cousins et al. (2009) demonstrated a possible 458 environmental control on the formation of bioalteration textures and in particular 459 showed that the subglacial environment was not as conducive to their formation as 
460 those that are oceanic. Likewise, while Cockell et al., (2009a) described biogenic

461 pitting in subglacially erupted hyaloclastites in Iceland, they also note an absence

462 of the characteristic tubular textures seen in oceanic lavas. Bioalteration textures

463 therefore may not necessarily be the most suitable biosignature for identifying

464 past life within subglacial basaltic lavas, and other alternative options, such as

465 geochemical biosignatures, should also be explored. For example, distinctive trace

466 element ( $\mathrm{Zr}, \mathrm{Sc}$, and $\mathrm{Mn}$ ) signatures have been found to result from the utilization

467 of organic acids to dissolve basaltic substrates (Hausrath et al., 2007; Hausrath et

468 al., 2009). Likewise, sulphur isotope $\left({ }^{32} \mathrm{~S},{ }^{33} \mathrm{~S},{ }^{34} \mathrm{~S}\right)$ compositions can provide

469 evidence of microbial sulphate reduction within altered oceanic basalts (Rouxel et

470 al., 2008).

471

\section{6. Discussion \& Conclusions}

473 An active volcano - ice system can potentially provide all the necessary 474 ingredients for life. The continual release of geothermal heat into an overlying 475 glacier can sustain a subsurface meltwater environment, while the release of 476 volcanic gases such as $\mathrm{H}_{2} \mathrm{~S}, \mathrm{CO}, \mathrm{CO}_{2}$, and $\mathrm{H}_{2}$ could support a variety of 477 chemosynthetic metabolisms. The presence of this heat flow will also mean that a 478 continual convective system will create a cycling of material through the different 479 environments, which will remove waste products from some niches and deliver 480 nutrients to others. 
481

482 It is clear that the presence of liquid meltwater is key to glaciovolcanic systems 483 being suitable for life, but there are significant differences between terrestrial and

484 martian systems that need consideration. On Mars, the melting efficiency of water 485 ice is much reduced due to the low initial temperature of the ice (Hovius et al., 486 2008), which perhaps suggests volcano - ice systems on Mars were not as viable 487 as those on Earth. Indeed, there are locations on Mars interpreted to be the result 488 of subglacial volcanism that display a distinct lack of evidence for meltwater. 489 Such places include the proposed subglacial lava flows at Ascraeus Mons, where 490 rapid re-freezing of a cold-based glacier would prevent any significant basal 491 melting (Kadish et al., 2008). However, it is thought that the temperature of the 492 meltwater is highly influential on the formation of jökulhlaups, whereby higher 493 heat flow enables the enlargement of subglacial drainage tunnels (Gudmundsson 494 et al., 1997). The occurrence of jökulhlaup-like flows and deposits on Mars 495 therefore suggests that subglacial eruptions can lead to significant subglacial 496 melting, even with cold-based glaciers (Head \& Wilson 2007).

497

498 While habitable environments potentially may exist in this subglacial volcanic 499 setting on Mars, they are most likely to be transient and isolated. On Earth, any 500 new body of liquid water will be rapidly colonized due to the widespread and 501 globally connected biosphere (Cockell \& Lim 2005). While it remains possible 
502 that pockets of martian life could exist, as yet there is no evidence for a martian

503 biosphere. As a result, the delivering of martian life, should it exist, to newly

504 formed habitable environments remains a problem. It can be seen that, in Iceland,

505 features indicative of subglacial volcanic activity often occur in clusters (e.g.,

506 Alfaro et al., 2007), which suggests that localized habitable regions may exist

507 within a close enough proximity to allow transport of microorganisms between

508 individual niches. On Earth, regions of high heat flow are rarely isolated to just

509 one volcano. Indeed, in the case of Iceland, Vatnajökull (glacier) overlies seven

510 individual volcanic centers. Additionally, it has been observed that rapid vertical

511 transport of hydrothermal fluid occurs beneath Mýrdalsjökull via faults within the

512 ice (Björnsson 2002). Therefore, it is possible to envisage such subglacial systems

513 to be connected via fractures and channels within the ice, where meltwater (and

514 any microbial life it may carry) may circulate, distributing microorganisms from

515 one system to another.

517 The vast majority of the terrestrial biosphere is dependant upon photosynthesis,

518 either directly or indirectly (Varnes et al., 2003). Photosynthesis on Mars,

519 however, would be hindered by the exposure to UV radiation and by the increased

520 distance to the Sun, which reduces the flux of photosynthetically active radiation

521 (PAR) to $\sim 55 \%$ of that typically experienced on Earth (Cockell \& Raven 2004). If

522 photosynthetic communities were to exist within a subglacial volcanic system, 
523 they would be limited to the near-surface ice and specifically use blue and green

524 wavelengths due to the high absorbance of red light within ice (Hawes \& Schwarz

525 2000). Cockell \& Raven (2004) showed experimentally that the maximum depth

526 within snow-pack at which the minimum level of PAR can penetrate is $\sim 24 \mathrm{~cm}$.

527 Additionally, work on ice-covered lakes in Antarctica has shown there to be 528 benthic photosynthetic communities residing at $\sim 16 \mathrm{~m}$ water depth beneath $3.5-$

$5295 \mathrm{~m}$ of ice cover (Vopel \& Hawes 2006), which is much shallower than the depths

530 of many subglacial volcanic systems, which are typically beneath several hundred

531 meters of overlying ice (Wilson \& Head 2002). At depths of 100m within glacial

532 ice, PAR is entirely absent (Warren et al., 2002). Subglacial volcanic

533 environments, therefore, are not suited to a photosynthesis-based community. This

534 limits the primary producers of this environmental setting to chemosynthetic 535 pathways.

536

537 On Earth, chemoautotrophs are major contributors for communities residing 538 within dark, extreme environments, such as deep sea vents (McCollom \& Shock 539 1997; Van Dover 2000). Specifically to Mars, anaerobic chemolithoautotrophs 540 can potentially inhabit subglacial volcanic environments through the oxidation of 541 inorganic compounds and fixation of carbon dioxide as the carbon source (Boston 542 et al., 1992). Numerous chemosynthetic pathways could be exploited due to the 543 chemical disequilibrium that results from the mixing of high- and low-temperature 
544 fluids (Gaidos \& Marion 2003). On Earth, the majority of the chemosynthetic

545 microbial communities residing in present-day hydrothermal systems are

546 indirectly dependent on photosynthetically produced $\mathrm{O}_{2}$ (Varnes et al., 2003).

547 However, an estimated $1-2 \%$ of these communities obtain chemical energy from

548 redox reactions that are completely independent of photosynthesis (Varnes et al.,

549 2003), and it is these microorganisms and their metabolic pathways that are

550 potentially suitable for survivability on Mars, particularly within subglacial

551 hydrothermal systems.

552

553 In conclusion, the conditions that exist as a result of volcano - ice interaction

554 provide a wide range of habitats for life on Earth and may have provided a

555 possible subsurface haven for life on Mars during past epochs. While there is still

556 much work to be done with regard to understanding the thermal and geochemical

557 conditions of such environments on Mars, the combination of basaltic lava, liquid

558 water, and hydrothermal activity provides a possible subsurface haven for life.

559 The wide range of geological deposits - be it jökulhlaup sediments, hydrothermal

560 minerals, or subglacial basalt - provides several mechanisms for the preservation

561 of any biosignatures for future discovery.

562

563 Acknowledgements 
564 This work is funded by the Leverhulme Trust. Field observations made in Iceland 565 in July 2007 were additionally supported by a Birkbeck College Faculty Research

566 Grant; we thank Dr. Katie Joy and Dr. Oliver White for field assistance whilst in

567 Iceland. Finally we especially thank Dr. Nick Warner for assistance with Mars

568 images and detailed comments, and two other anonymous reviewers for their 569 suggested revisions that significantly improved the manuscript.

571 FIGURES \& TABLES

572 FIG. 1. Icelandic examples of subglacial volcanic products and environments. a) 573 Tuya (Herðubreið) with car for scale; b) Pillow mound, in central Iceland (people 574 on left for scale); c) Sandur subglacial outwash plain in south Iceland (road bridge

575 for scale); d) Glacier cave at Kverkfjöll; e) Subaerial glacial meltwater lake 576 ( 500m across) above the subglacial volcano Kverkfjöll; f) fumaroles and hot 577 springs interacting with the glacier surface at Kverkfjöll volcano. 578

579 FIG. 2. Simplified diagram showing the processes of volcano - ice interaction: a) 580 initial subglacial eruption into overlying ice, creating a meltwater lens and ice 581 cauldron at the glacier surface; b) emergent eruption, whereby sustained volcanic 582 activity eventually melts through the ice, resulting in subaerial capping lavas 583 when the edifice becomes higher than the waterline, forming a tuya morphology; 
584 c) subaerial hot springs and fumaroles at the glacier surface, sourced by surface

585 glacial meltwater and underlying geothermal activity.

586

587 FIG. 3. Map of localities given in Table 1 (Image credit: National Geographic 588 Society, MOLA Science Team, MSS, JPL, NASA).

590 FIG. 4. Geological time scales for Mars (left) and the corresponding divisions for

591 Earth (right). Boundary variations for both the Neukum ('N') or Hartmann ('H')

592 chronology models (Hartmann \& Neukum 2001) are shown.

593

594 FIG. 5. Examples of putative glaciovolcanic features on Mars as described in the 595 text and given in Table 1. a) Mesa at Acidalia Planitia interpreted as a possible 596 tuya (Martinez-Alonso et al., 2011; HiRISE image PSP_009497_2210_RED) ; b) 597 putative subglacially erupted dykes near the Elysium Volcanic Province (Pedersen 598 et al., 2010; HiRISE image PSP_006591_2165); c) Chasma Boreale (Fishbaugh $599 \&$ Head 2002; MOLA shaded relief map overlain on a THEMIS IR day $100 \mathrm{~m}$ 600 mosaic); d) large drainage channels in the Athabasca Valles (Burr et al., 2002; 601 MOC image M2101914); e) Interior Layered Deposit in Juventae Chasma 602 (Chapman 2003; MRO CTX image B18_016712_1762_XN_03S061W); f) 603 pseudocraters or "rootless cones" north of the Cerberus plains (Fagents et al., 
604 2002; MOC image M08/01962); g) ice-cauldron morphology at Galaxias Fossae 605 (Levy et al., 2010; HiRISE image PSP_005813_2150).

606

607 FIG. 6. More examples of putative glaciovolcanic features on Mars as described 608 in the text and given in Table 1. a) broad view of the Dorsa Argentea Formation 609 with numerous inverted linear features, shown in more detail in Figure 5c (Ghatan 610 \& Head 2004; (MOLA shaded relief map overlain on a THEMIS IR day $100 \mathrm{~m}$ 611 mosaic); b) Chaos terrain and drainage channels at Xanthe Terra (Chapman \& 612 Tanaka 2002; MOLA shaded relief map overlain on a THEMIS IR day $100 \mathrm{~m}$ 613 mosaic); c) Inverted linear features interpreted as eskers (Ghatan \& Head 2004, 614 MRO CTX image P13_006282_1046_XN_75S043W); d) volcano Ceraunius 615 Tholes showing evidence of floodwater originating at the caldera rim (Fassett \& 616 Head 2007; MRO CTX image B04_011399_2045_XN_24N097W).

617

618 Table 1. Examples of candidate volcano - ice interaction features identified on 619 Mars, and their associated terrestrial analogue (where given). Alternative 620 interpretations of these sites are also shown for comparison.

621

622 Table 2. Physicochemical characteristics and resident biota present within 623 terrestrial volcano - ice related environments. 624 


\section{REFERENCES}

626 Alfaro, R., Brandsdottir, B., Rowlands, D.P., White, R.S. and Gudmundsson, 627 M.T. (2007) Structure of the Grimsvötn central volcano under the Vatnajökull 628 icecap, Iceland. Geophysical Journal International 168: 863 - 876.

629

630 Allen, C.G. (1979) Volcano-ice interactions on Mars. Journal of Geophysical 631 Research 84: $8048-8059$.

632

633 Allen, C.C., Albert, F.G., Chafetz, H.S., Combie, J., Graham, C.R., Kieft, T.L., 634 Kivett, S.J., McKay, D.S., Steele, A., Taunton, A.E., Taylor, M.R., Thomas635 Keprta, K.L., Westall, F. (2000) Microscopic Physical Biomarkers in Carbonate 636 Hot Springs : Implications in the Search for Life on Mars. Icarus 147: 49 - 67.

637

638 Baker, V.R., Strom, R.G., Gulick, V.C., Kargel, J.S., Komatsu, G., Kale, V.S. 639 (1991) Ancient oceans, ice sheets and the hydrological cycle on Mars. Nature $640 \quad 352: 589-594$.

641

642 Baker, V. (2001) Water and the martian landscape. Nature 412: 228-236.

643

644 Banerjee, N.R., Furnes, H., Simonetti, A., Muehlenbachs, K., Staudigel, H., 645 deWit, M.,Van Kranendonk, M. (2006) Ancient microbial alteration of oceanic 
646 crust on two early Archean Cratons and the search for extraterrestrial life [abstract 647 2156]. In $37^{\text {th }}$ Lunar and Planetary Science Conference Abstracts, Lunar and 648 Planetary Institute, Houston.

649

650 Banerjee, N. R., Muehlenbachs, K., Furnes, H., Staudigel, H., de Wit, M. (2004)

651 Potential for early life hosted in basaltic glass on a wet Mars [abstract 8048]. In:

652 Proceedings of the Second Conference on Early Mars, Jackson Hole,WY, October $653 \quad 11-15$.

654

655 Bibring, J-P., Langevin, Y., Mustard, J.F., Poulet, F., Arvidson, R., Gendrin, A., 656 Gondet, B., Mangold, N., Pinet, P., Forget, F., the OMEGA team. Global 657 Mineralogical and Aqueous Mars History Derived from OMEGA/Mars Express 658 Data. Science 312: 400 - 404.

659

660 Bishop, J.L., Parente, M., Weitz, C.M., Dobrea, E.Z.N., Roach, L.H., Murchie, 661 S.L., McGuire, P.C., McKeown, N.K., Rossi, C.M., Brown, A.J., Calvin, W.M., 662 Milliken, R., Mustard, J.F. (2009) Mineralogy of Juventae Chasma: Sulfates in the 663 light-tonedmounds,maficminerals in the bedrock, and hydrated silica and 664 hydroxylated ferric sulfate on the plateau, J. Geophys. Res., 665 114,doi:10.1029/2009JE003352

666 
667 Blake, D.F, Amundsen, H.E.F., Benning, L., Bish, D., Conrad, P., Fogel, M., 668 Midtkandal, I., Ming, D., Steele, A., Treiman, A.H. and the AMASE team. 669 Carbonate cements from the Sverrefjell and Sigurdfjell volcanoes, Svalbard 670 Norway: Terrestrial analogues for martian carbonates? [abstract 5119]. In 671 Astrobiology Science Conference 2010: Evolution of Life: Surviving Catastrophes 672 and Extremes on Earth and Beyond, Lunar and Planetary Institute, Houston.

673

674 Björnsson, H. (2002) Subglacial lakes and Jökulhlaups in Iceland. Global and $675 \quad$ Planetary Change 35: 255 - 271.

676

677 Boston, P.J., Ivanov, M.V., McKay, C.P. (1992) On the Possibility of 678 Chemosynthetic Ecosystems in Subsurface Habitats on Mars. Icarus 95: 300 679308.

680

681 Bourgeois, O., Dauteuil, O., Van Vliet-Lanoe, B. (1998) Pleistocene subglacial 682 volcanism in Iceland: tectonic implications. Earth and Planetary Science Letters 683 164: $165-178$.

684

685 Burr, D.M., Grier, J.A., McEwen, A.S., Keszthelyi, L.P. (2002b) Repeated 686 Aqueous Flooding from the Cerberus Fossae: Evidence for Very Recently Extant, 687 Deep Groundwater on Mars. Icarus 159: 53-73. 
688

689 Burr, D.M., McEwen, A.S., Sakimoto, S.E.H. (2002a) Recent aqueous floods

690 from the Cerberus Fossae, Mars. Journal of Geophysical Research 29,

691 doi:10.1029/2001GL013345.

692

693 Carr, M.H. (1979) Formation of Martian Flood Features by Release of Water from

694 Confined Aquifers. J.Geophys Res 84: 2995 - 3007.

695

696 Carr, M.H. (1987) Water on Mars. Nature 326: 30-35.

697

698 Carr, M.H., Head, J.W (2003) Basal melting of snow on early Mars: A possible

699 origin of some valley networks. Geophysical Research Letters 30: 2245, doi:

$700 \quad 10.1029 / 2004 G L 018575$

701

702 Catling, D. C., S. E. Wood, C. B. Leovy, D. R. Montgomery, H. M.

703 Greenberg, C. R. Glein, and J. M. Moore (2006), Light-toned layered deposits in

704 Juventae Chasma, Mars, Icarus, 181, 26-51.

705

706 Cavicchioli, R. (2002) Extremophiles and the Search for Extraterrestrial Life.

707 Astrobiology 2: $281-292$.

708 
709 Channing, A., Butler, I.B. (2007) Cryogenic opal-A deposition from Yellowstone

710 hot springs. Earth and Planetary Science Letters 257: 121 - 131.

711

712 Chapman, M. G. (2003) Sub-ice volcanoes and ancient oceans/lakes: a Martian

713 challenge. Global and Planetary Change 35: 185 - 198.

714

715 Chapman, M.G., Allen, C.C., Guðmundsson, M.T., Gulick, V.C., Jakobsson, S.P.,

716 Lucchita, B.K., Skilling, S.P., and Waitt R.B. (2000) Volcanism and ice

717 interactions on Earth and Mars. In: J.R. Zimbelman and T.K.P. Gregg, Editors,

718 Environmental Effects on Volcanic Eruptions, Kluwer Academic, New York

719 (2000), pp. 39-73.

720

721 Chapman, M.G., Tanaka, K.L., (2002) Related magma-ice interactions: possible 722 origins of chasmata, chaos, and surface materials in Xanthe, Margaritifer, and 723 Meridiani Terrae, Mars. Icarus 155: 324-339.

725 Chapman, M.G., and Tanaka, K.L., (2001) Interior trough deposits on Mars:

726 Sub-ice volcanoes? J. Geophys Res, 106(E5), 10,087-10,000.

727

728 Chevrier, V., Poulet, F., Bibring, J-P. (2007) Early geochemical environment of 729 Mars as determined from thermodynamics of phyllosilicates. Nature 448: 60 - 63. 
730

731 Christensen, P.R., Bandfield, J.L., Bell, J.F., Gorelick, N., Hamilton, V.E., 732 Ivanov, A., Jakpsky, B.M., Kieffer, H.H., Lane, M.D., Malin, M.C.,

733 McConnochie, T., McEwen, A.S., McSween, H.Y., Mehall, G.L., Moersch, J.E., 734 Nealson, K.H., Rice, J.W., Richardson, M.I., Ruff, S.W., Smith, M.D., Titus,

735 T.N., Wyatt, M.B. (2003) Morphology and Composition of the Surface of Mars:

736 Mars Odyssey THEMIS Results. Science 300: 2056-2061.

737

738 Clifford, S. (1987) Polar basal melting on Mars. J. Geophys Res. 92: 9135-9152.

739

740 Clifford, S.M. (1993) A model for the hydrologic and climatic behaviour of water

741 on Mars. J. Geophys Res 98: 10973-11016.

742

743 Clifford, S.M., Lasue, J., Heggy, E., Boisson, J., McGovern, P., Max, M.D.

744 (2010) Depth of the Martian cryosphere: Revised estimates and implications for

745 the existence and detection of subpermafrost groundwater. J. Geophys Res115,

746 E07001, doi:10.1029/2009JE003462.

747

748 Cockell C. and Lim D.S.S. (2005) Impact Craters, Water and Microbial Life. In 749 Water on Mars and Life. Advances in Astrobiology and Biogeophysics, Tokano

750 T. (ed.), pp. 261-275. 
752 Cockell, C.S., Olsson-Francis, K., Herrera, A., and Meunier, A. (2009a)

753 Alteration textures in terrestrial volcanic glass and the associated bacterial 754 community. Geobiology 7: 50 -65.

755

756 Cockell, C.S., Olsson, K., Knowles, F., Kelly, L., Herrera, A., Thorsteinsson, T., 757 Marteinsson, V. (2009b) Bacteria in Weathered Basaltic Glass, Iceland. 758 Geomicrobiology Journal 26: 491 - 507.

759

760 Cockell C.S, Raven J.A. (2004) Zones of photosynthetic potential on Mars and 761 the early Earth. Icarus 169: 300-310.

762

763 Coleman, N.M. (2003), Aqueous flows carved the outflow channels on Mars, J J.

764 GeophysRes 108 (E5), 5039, doi:10.1029/2002JE001940.

765

766 Costello, E.K., Halloy, S.R.P., Reed, S.C., Sowell, P. Schmidt, S.K. (2009)

767 Fumarole-Supported Islands of Biodiversity within a Hyperarid, High-Elevation

768 Landscape on Socompa Volcano, Puna de Atacama, Andes. Applied 769 Environmental Microbiology 75: $735-747$.

770 
771 Cousins, C.R. (2010) An Astrobiological Study of High Latitude Martian

772 Analogue Environments. Unpublished PhD Thesis, University College London.

773

774 Cousins, C.R., Smellie, J.L., Jones, A.P., Crawford, I.A. (2009) A comparative

775 study of endolithic microborings in basaltic lavas from a transitional subglacial -

776 marine environment. International Journal of Astrobiology 8: 37 - 49

777

778 Craddock, R.A., Howard, A.D. (2002) The case for rainfall on a warm, wet early

779 Mars. J. Geophys Res107 (E11): 5111, doi:10.1029/2001JE0011505

780

781 Dickson, J., Head, J.W. (2006) Evidence for an Hesperian-aged South Circum-

782 Polar Lake Margin Environment on Mars. Planetary and Space Science 54: 251 783272.

784

785 Edwards, B.R., Russell, J.K., Anderson R.G. (2002) Subglacial, phonolitic

786 volcanism at Hoodoo Mountain volcano, northern Canadian Cordillera. Bulletin of

$787 \quad$ Volcanology 64: $254-272$.

788

789 Edwards, K.J., Rogers, D.R., Wirsen, C.O., McCollom, T.M. (2003) Isolation and

790 characterization of novel psychrophilic, neutrophilic, Fe-oxidizing, 
791 chemolithoautotrophic alpha- and gamma-Proteobacteria from the deep sea.

792 Applied and Environmental Microbiology 69: 2906 - 2913.

793

794 Edwards, H.G.M., Mohsin, M.A., Sadooni, F.N., Nik Hassan, N.F. Munshi, T. 795 (2006) Life in the sabkha: Raman spectroscopy of halotrophic extremophiles of 796 relevance to planetary exploration. Analytical and Bioanalytical Chemistry 385: $797 \quad 46-56$.

798

799 Ehlmann, B.L., Mustard, J.F., Fassett, C.I., Schon, S.C., Head, J.W., Des Marais, 800 D.J., Grant, J.A., Murchie, S.L. (2008) Clay minerals in delta deposits and organic 801 preservation potential on Mars. Nature Geoscience 1: 355 - 358.

802

803 Fagents, S.A., Thordarson, T. (2007) Rootless volcanic cones in Iceland and on 804 Mars. In The Geology of Mars: Evidence from Earth-Based Analogs edited by M.

805 G. Chapman Published by Cambridge University Press, Cambridge, UK, pp.151. 806

807 Farmer, J.D. (1996) Hydrothermal systems on Mars: an assessment of present 808 evidence. In Evolution of hydrothermal ecosystems on Earth (and Mars?). Wily, 809 Chichester (Ciba Foundation Symposium 202), p.p. 273 - 299.

810 
811 Fasset, C.I., Head, J.W. (2006) Valleys on Hecates Tholus, Mars: origin by basal

812 melting of summit snowpack. Planetary and Space Science 54: 370-378.

813

814 Fassett, C.I., Head, J.W. (2007) Valley formation on martian volcanoes in the

815 Hesperian: Evidence for melting of summit snowpack, caldera lake formation,

816 drainage and erosion on Ceraunius Tholus. Icarus 189: 118 - 135.

817

818 Fishbaugh, K. and Head, J. (2002). Chasma Boreale, Mars: Topographic

819 Characterization from MOLA data and implications for mechanisms of 820 formation. J. Geophys Res 107 (E3), doi:10.1029/2000JE001351.

821

822 Fisk, M.R., Giovannoni, S.J. (1999), Sources of nutrients and energy for a deep 823 biosphere on Mars. J. GeophysRes104: 11805-11815.

824

825 Forget, F., Haberle, R.M., Montmessin, F., Levrard, B., Head, J.W. (2006)

826 Formation of Glaciers on Mars by Atmospheric Precipitation at High Obliquity.

$827 \quad$ Science 311: $368-371$.

828

829 Furnes, H., Banerjee, N.R., Staudigel, H., Muehlenbachs, K., McLoughlin, N., de 830 Wit, M., Van Kranendonk, M.V. (2007) Comparing petrographic signatures of 
831 bioalteration in recent to Mesoarchean pillow lavas: Tracing subsurface life in 832 oceanic igneous rocks. Precambrian Research 158: 156-176.

833

834 Gaidos, E., Marion, G. (2003) Geological and geochemical legacy of a cold early

835 Mars. J. Geophys Res, 108, doi:10.1029/2002JE002000

836

837 Gaidos, E., Mareinsson, V., Thorsteinsson, T., Johannesson, T., Runarsson, A. R., 838 Stefansson, A., Glazer, B., Lanoil, B., Skidmore, M., Han, S., Miller, M., Rusch, 839 A., Foo, W. (2008) An oligarchic microbial assemblage in the anoxic bottom 840 waters of a volcanic subglacial lake. ISME Journal. 3: 486 - 497.

841

842 Gaidos, E., Lanoil, B., Thorsteinsson, T., Graham, A., Skidmore, M., Han, S., 843 Rust, T, Popp, B. (2004) A Viable Microbial Community in a Subglacial Volcanic 844 Crater Lake, Iceland. Astrobiology 4: 327 - 344.

845

846 Ghatan, G.J. and Head, J.W. (2002) Candidate subglacial volcanoes in the south 847 polar region of Mars: Morphology, morphometry, and eruption conditions. $J$. 848 Geophys Res 107, doi: 10.1029/2001JE001519 
850 Ghatan, G.J., Head, J.W. (2003) Cavi Angusti, Mars: characterization and 851 assessment of possible formation mechanisms. $J$ Geophys Res. 108 852 doi:10.1029/2002JE001972.

853

854 Ghatan, G.J., Head, J.W. (2004) Regional drainage of meltwater beneath a 855 Hesperian aged south circumpolar ice sheet on Mars. J. Geophys Res. 109, doi: $856 \quad 10.1029 / 2003 J E 002196$

857

858 Gilichinsky, D.A., Wilson, G.S., Friedmann, E.I., Mckay, C.P., Sletten, R.S., 859 Rivkina, E.M., Vishnivetskaya, T.A., Erokhina, L.G., Ivanushkina, N.E., 860 Kochkina, G.A., Shcherbakova, V.A., Soina, V.S., Spirina, E.V., Vorobyova, 861 E.A., Fyodorov-Davydov, D.G., Hallet, B., Ozerskaya, S.M., Sorokovikov, V.A. 862 Laurinavichyus, K.S., Shatilovich, A.V., Chanton, J P., Ostroumov, V.E., Tiedje, 863 J.M. (2007) Microbial Populations in Antarctic Permafrost: Biodiversity, State, 864 Age, and Implication for Astrobiology. Astrobiology 7: 275 - 311.

866 Greve, R. (2008) Scenarios for the formation of Chasma Boreale, Mars. Icarus 867 196: $359-367$. 
869 Gudmundsson, M.T., Sigmundsson, F., Björnsson, H. (1997) Ice-volcano

870 interaction of the 1996 Gjalp subglacial eruption, Vatnajökull, Iceland. Nature $871 \quad 389: 954-957$.

872

873 Gudmundsson, M.T., Sigmundsson, F., Bjornsson, H., Hognadottir, T. (2004) The

8741996 eruption at Gjálp, Vatnajökull ice cap, Iceland: efficiency of heat transfer, 875 ice deformation and subglacial water pressure. Bull Volcanol 66: 46 - 65.

876

877 Gudmundsson, M.T. and the Eyjafjallajökull Team (2010) The April 2010 878 eruption of the ice-capped Eyjafjallajökull, South Iceland. Geophysical Research 879 Abstracts 12: EGU2010-15733. EGU General Assembly 2010, held 2-7 May, 8802010 in Vienna, Austria, p.15733

881

882 Gulick, V. C. (1998) Magmatic intrusions and a hydrothermal origin for fluvial 883 valleys on Mars. J.GeophysRes103: 19365-19387.

884

885 Hartmann, W.K. (2005) Martian cratering 8: Isochron refinement and the 886 chronology of Mars. Icarus. 174: 294-320.

887

888 Hartmann, W.K. (2001) Cratering chronology and the evolution of Mars. Space 889 Science Reviews, 96: 165 - 194. 
890

891 Hausrath, E.M., Liermann, L.J., House, C.H., Ferry, J.G., Brantly, S.L. (2007)

892 The effect of methanogen growth on mineral substrates: will Ni markers of

893 methanogen-based communities be detectable in the rock record? Geobiology 5:

894 49-61.

895

896 Hausrath, E.M., Neaman, A., Brantley, S.L. (2009) Elemental release rates from

897 dissolving basalt and granite with and without organic ligands. American Journal 898 of Science 309: 633 - 660.

899

900 Hawes, I., Schwarz, A-M. J. (2000) Absorption and utilization of irradiance by

901 cyanobacterial mats in two ice-covered Antarctic lakes with contrasting light 902 climates. Journal of Phycology 37: 5 - 15.

903

904 Head, J.W., Wilson, L. (2002) Mars: a review and synthesis of general 905 environments and geological settings of magma-H2O interactions. In Volcano 906 Ice Interaction on Earth and Mars, edited by J.L. Smellie \& M.G. Chapman, 907 Geological Society, London, Special Publications 202, p.p. 27 - 57.

908

909 Head, J.W., Wilson, L. and Mitchell, K. L. (2003) Generation of recent massive 910 water floods at Cerberus Fossae, Mars by dike emplacement, cryospheric 
911 cracking, and confined aquifer groundwater release. Geophysical Research

912 Letters, 30, doi:10.1029/2003GL017135

913

914 Head, J.W. and Wilson, L. (2007) Heat transfer in volcano-ice interactions on

915 Mars: synthesis of environments and implications for processes and landforms.

916 Annals of Glaciology 45: 1 - 13.

917

918 Head, J.W., and S. Pratt (2001), Extensive Hesperian-aged South Polar ice sheet

919 on Mars: Evidence for massive melting and retreat, and lateral flow and ponding 920 of meltwater. J.GeophysRes 106: 12,275- 12,299.

921

922 Head, J.W., Mustard, J.F., Kreslavsky, M. A., Milliken, R.E., Marchant, D.R. 923 (2003) Recent ice ages on Mars. Nature 426: 797 - 802.

924

925 Herrera, A. Cockell, C. S., Self, S., Blaxter, M., Reitner, J., Thorsteinsson, T., 926 Arp, G., Drose, W., Tindle, A. G. (2009) A Cryptoendolithic Community in 927 Volcanic Glass. Astrobiology 9: 369 - 381.

928

929 Hoffman, N., Kyle, P.R. (2003) The Ice Towers of Mt. Erebus as analogues of 930 biological refuges on Mars [abstract 3105]. Sixth International Conference on 931 Mars, Pasadena, California.USA. 
932

933 Holt, J.W., Fishbaugh, K.E., Byrne, S., Chistian, S., Tanaka, K., Russell, P.S.,

934 Herkenhoff, K.E., Safaeinili, A., Putzig, N.E., Phillips, R.J. The construction of

935 Chasma Boreale on Mars. Nature 465: 446 - 449.

936

937 Höskuldsson, A., Sparks, R.S.J (1997) Thermodynamics and fluid dynamics of 938 effusive subglacial eruptions. Bulletin of Volcanology 59: 219 - 230.

939

940 Hovius, N., Lea-Cox, A. and Turowski, J.M. (2008) Recent volcano-ice

941 interaction and outburst flooding in a Mars polar cap re-entrant. Icarus 197: 2494238.

943

944 Hvidberg, C.S. (2005) Polar Caps. In Water on Mars and Life, edited by Tetsuya 945 Tokano, Adv. Astrobiol. Biogeophys. pp.129 - 152.

946

947 Izawa, M.R.M., Banerjee, N.R., Flemming, R.L., Bridge, N.J., Schultz, C. (2010)

948 Basaltic glass as a habitat for microbial life: Implications for astrobiology and 949 planetary exploration. Planetary and Space Science 58: 583-591.

950

951 Jakobsson \& Gudmundsson (2008) Subglacial and intraglacial volcanic 952 formations in Iceland. Jökull 58: 179 - 196. 
953

954 Jakosky, B.M. and Phillips, R.J. (2001) Mars' volatile and climate history. Nature $955 \quad 412: 237-244$.

956

957 Johannesson, T., Thorsteinsson, T., Stefansson, A., Gaidos, E.J., Einarsson, B. 958 (2007) Circulation and thermodynamics in a subglacial geothermal lake under the 959 Western Skafta cauldron of the Vatnajokull ice cap, Iceland. Geophysical 960 Research Letters 34, doi:10.1029/2007GL030686

961

962 Kadish, S.J., Head, J.W., Parsons, R.L. and Marchant, D.R. (2008) The Ascraeus

963 Mons fan-shaped deposit: Volcano-ice interactions and the climatic implications 964 of cold-based tropical mountain glaciation. Icarus 197: 84 - 109.

965

966 Kargel, K.S., Strom, R.G. (1992) Ancient glaciations on Mars. Geology 20: 3-7.

967 Kiver, E.P., Mumma, M.D. (1971) Summit Firn Caves, Mount Rainier,

968 Washington. Science 23, 320 - 322.

969

970 Kelly, L.C., Cockell, C.S., Piceno, Y.M., Andersen, G.L., Thorsteinsson, T., 971 Marteinsson, V. (2010) Bacterial Diversity of Weathered Terrestrial Icelandic 972 Volcanic glasses. Microbial Ecology 60: 740 - 752.

973 
974 Kiver, E.P. and Steele, W.K., (1975) Firn caves in the volcanic craters of Mount

975 Rainier, Washington. National Spel. Soc. Bull. 37: 45-55.

976

977 Kuzmin, R.O. (2005) Ground Ice in the Martian Regolith. In Water on Mars and 978 Life, edited by Tetsuya Tokano, Adv. Astrobiol. Biogeophys., pp. 155 - 189.

979

980 Leask, H.J., Wilson, L. and Mitchell K.L. (2006) Formation of Aromatum Chaos, 981 Mars: Morphological development as a result of volcano-ice interactions, Journal 982 of Geophysical Research 111, doi:10.1029/2005JE002549

983

984 Léveillé, R.J., Datta, S. (2010) Lava tubes and basaltic caves as astrobiological 985 targets on Earth and Mars: A review. Planetary and Space Science 58: 592 - 598. 986

987 Levy, J.S., Marchant, D.R., Head, J.W. (2010) Thermal contraction crack 988 polygons on Mars: A synthesis from HiRISE, Phoenix, and terrestrial analog 989 studies. Icarus 206: 229-252.

990

991 Levy, J.S., Head, J.W., Fassett, C.I., Fountain, A.G. (2010) Candidate volcanic 992 ice-cauldrons on Mars: Estimates of ice melt, magma volume, and astrobiological 993 implications [abstract 1533]. In $41^{\text {st }}$ Lunar and Planetary Science Conference 994 abstracts, The Woodlands, Texas. 
995

996 Lysnes, K., Thorseth, I. H., Steinsbu, B. O., Øvreas, L., Torsvik, T., and Pedersen,

997 R. B. (2004) Microbial community diversity in seafloor basalt from the Arctic 998 spreading ridges. FEMS Microbial Ecology 50: 213 - 230.

999

1000 Mader, H.M., Pettitt, M.E., Wadham, J.L., Wolff, E.W., Parks, R.J. (2006) Life in 1001 subsurface ice, Geology 34: 169-172.

1002

1003 Martin, W., Baross, J., Kelley, D., Russell, M.J. (2008) Hydrothermal vents and 1004 the origin of life. Nature Reviews Microbiology 6: 805-814.

1005

1006 Martinez-Alonso, S., Mellon, M.T., Banks, M.E., Keszthelyi, L.P., McEwen, 1007 A.S., and The HiRISE Team. (2011) Evidence of volcanic and glacial activity in 1008 Chryse and Acidalia Planitiae, Mars. Icarus 212: 597 - 621.

1009

1010 McCollom, T.M. and Shock, E.L. (1997) Geochemical constraints on 1011 chemolithoautotrophic metabolism by microorganisms in seafloor hydrothermal 1012 systems. Geochimica et Cosmochimica Acta 61, 4375 - 4391.

1013

1014 McKenzie, D. and Nimmo, F. (1999) The generation of Martian floods by the 1015 melting of ground ice above dykes. Nature 397: 231-233 
1016

1017 McKeown, N.K., Bishop, J.L., Dobrea, E.Z.N., Ehlmann, B.L., Parente, M.,

1018 Mustard, J.F., Murchie, S.L., Swayze, G.A., Bibring, J-P., Silver, E.A. (2009)

1019 Characterization of phyllosilicates observed in the central Mawrth Vallis region,

1020 Mars, their potential formation processes and implications for past climate. $J$.

1021 Geophys Res114, doi:10.1029/2008JE003301

1022

1023 McKinley, J.P., Stevens, T.O. (2000) Microfossils and Paleoenvironments in

1024 Deep Subsurface Basalt Samples. Geomicrobiology Journal, 17, 43 - 54.

1025

1026 McLoughlin, N., Furnes, H., Banerjee, N.R., Muehlenbachs, K., Staudigel, H.

1027 (2009) Ichnotaxonomy of microbial trace fossils in volcanic glass. Journal of the

1028 Geological Society 166, $159-169$.

1029

1030 McLoughlin, N., Brasier, M.D., Wacey, D., Green, O.R., Perry, R.S. (2007) On

1031 Biogenicity Criteria for Endolithic Microborings on Early Earth and Beyond.

1032 Astrobiology 7: $10-26$.

1033

1034 McSween, H.Y., Taylor, G.J., Wyatt, M.B. (2009) Elemental Composition of the

1035 Martian Crust. Science 324: 736 - 739.

1036 
1037 Michalski, J.R., Noe Dobrea, E.Z. (2007) Evidence for a sedimentary origin of 1038 clay minerals in the Mawrth Vallis region, Mars. Geology 35, 951-954.

1039

1040 Milkovich, S.M., Head, J.W., Pratt, S. (2002) Meltback of Hesperian-aged ice1041 rich deposits near the south pole of Mars: Evidence for drainage channels and 1042 lakes. J. Geophys Res 107, doi:10.1029/2001JE001802

1043

1044 Montgomery, D.R., Gillespie, A. (2005) Formation of Martian outflow channels

1045 by catastrophic dewatering of evaporite deposits, Geology 33: 625-628.

1046

1047 Mustard, J.F., Ehlmann, B.L., Murchie, S.L., Poulet, F., Mangold, N., Head, J.W., 1048 Bibring, J.-P., Roach, L.H. (2009) Composition, morphology, and stratigraphy of 1049 Noachian crust around the Isidis basin. J. Geophys. Res. 114,. 1050 doi:10.1029/2009JE003349.

1051

1052 Navarro-Gonzalez, R., Rainey, F. A., Molina, P., Bagaley, D. R., Hollen, B. J., de 1053 la Rosa, J., Small, A. M., Quinn, R. C., Grunthaner, F. J., Ca'ceres, L., Gomez1054 Silva, B. and McKay, C. P. (2003) Mars-Like Soils in the Atacama Desert, Chile, 1055 and the Dry Limit of Microbial Life. Science 302, 1018 - 1021.

1056 
1057 Neukum, G., Jaumann, R., Hoffmann, H., Hauber, E., Head, J.W., Basilevsky,

1058 A.T., Ivanov, B.A., Werner, S.C., van Gasselt, S., Murray, J.B., McCord, T., The

1059 HRSC Co-Investigator Team. (2004) Recent and episodic volcanic and glacial

1060 activity on Mars revealed by the High Resolution Stereo Camera. Nature 432: 971

$1061-979$.

1062

1063 Ólafsson, M., Torfason, H., and Grönvold, K. (2000) Surface exploration and

1064 monitoring of geothermal activity in the Kverkfjöll geothermal area, central

1065 Iceland. Proceedings of the World Geothermal Congress 2000.

1066

1067 Payne, M.C., Farmer, J.D. (2001) Volcano-Ice Interactions and the Exploration

1068 for Extant Martian Life [abstract \#P22B-0549].. In 2001 AGU Fall Meeting,

1069 American Geophysical Union, Washington DC.

1070

1071 Pedersen, G.B.M., Head, J.W., Wilson, L. (2010) Formation, erosion and

1072 exposure of Early Amazonian dikes, dike swarms and possible subglacial

1073 eruptions in the Elysium Rise/Utopia Basin Region, Mars. Earth and Planetary

1074 Science Letters 294: 424 - 439.

1075 
1076 Pope, K.O., Kieffer, S.W. and Ames, D.E. (2006) Impact melt sheet formation on

1077 Mars and its implication for hydrothermal systems and exobiology. Icarus 183: 110789.

1079

1080 Priscu, J.C., Christner, B. C. (2004) Earth's icy biosphere, In Microbial Diversity

1081 and Bioprospecting, edited by A. Bull, ASM Press, Washington, D.C. pp. 1301082145

1083

1084 Poulet, F., Beaty, D.W., Bibring, J-P., Bish, D., Bishop, J.L., Dobrea, E.N., 1085 Mustard, J.F., Petit, S., Roach, L.H. (2009). Key Scientific Questions and Key 1086 Investigations from the First International Conference on Martian Phyllosilicates.

1087 Astrobiology 9: $257-267$.

1088

1089 Preston, L.J., Benedix, G.K., Genge, M.J., Sephton, M.A. (2008) A 1090 multidisciplinary study of silica sinter deposits with applications to silica 1091 identification and detection of fossil life on Mars. Icarus 198: 331 - 350.

1092

1093 Rathbun, J.A., Squyres, S.W. (2002) Hydrothermal Systems Associated with 1094 Martian Impact Craters. Icarus 157: 362 - 372.

1095 
1096 Rice, J.W. and Edgett, K.S. (1997) Catastrophic flood sediments in Chryse Basin,

1097 Mars, and Quincy Basin, Washington: application of sandar facies model. J.

1098 Geophys. Res. 102: 4185-4200.

1099

1100 Roberts, M.J. (2005) Jökulhlaups: A reassessment of floodwater flow through

1101 glaciers. Rev. Geophys., 43, doi:10.1029/2003RG000147

1102

1103 Rothschild, L. J. (1990) Earth Analogs for Martian Life. Microbes in Evaporites, a

1104 New Model System for Life on Mars. Icarus 88: 246 - 260.

1105

1106 Rouxel, O., Ono, S., Alt, J., Rumble, D., Ludden, J. (2008) Sulfur isotope

1107 evidence for microbial sulfate reduction in altered oceanic basalts at ODP Site

1108 801. Earth and Planetary Science Letters 268: 110 -123.

1109

1110 Santelli, C.M., Orcutt, B. N., Banning, E., Bach, W., Moyer, C. L., Sogin, M.L.,

1111 Staudigel, H., Edwards, K.J. (2008) Abundance and diversity of microbial life in

1112 ocean crust. Nature 453: $653-657$.

1113

1114 Schorghofer, N. (2007) Dynamics of ice ages on Mars. Nature 449: 192 - 194.

1115 
1116 Schulze-Makuch, D, Dohm, J.M., Fan, C., Fairen, A.G., Rodrigues, J.A.P., Baker,

1117 V.R., Fink, W. (2007) Exploration of hydrothermal targets on Mars. Icarus 189:

$1118 \quad 308-324$.

1119

1120 Smellie, J.L. (1999) Subglacial eruptions. In, Encyclopaedia of Volcanoes, edited

1121 by H. Sigurdsson Academic Press, San Diego (1999), p.p. 403-418.

1122

1123 Smellie, J.L. (2006) The relative importance of supraglacial versus subglacial

1124 meltwater escape in basaltic subglacial tuya eruptions: an important unresolved

1125 conundrum. Earth-Science Reviews 74: 241 -268.

1126

1127 Smellie, J.L. (2007) Quaternary vulcanism: subglacial landforms. In Encyclopedia

1128 of Quaternary Sciences. Edited by S.A.Elias. Elsevier, Amsterdam, pp. 784-798.

1129

1130 Smellie, J.L., Skilling, I.P. (1994) Products of subglacial volcanic eruptions under

1131 different ice thicknesses: two examples from Antarctica. Sedimentary Geology 91:

$1132115-129$.

1133

1134 Smellie, J.L., Johnson, J.S., McIntosh, W.C., Esser, R., Gudmundsson, M.T., 1135 Hambrey, M.J., van Wyk de Vries, B. (2008) Six million years of glacial history 
1136 recorded in the James Ross Island Volcanic Group, Antarctic Peninsula.

1137 Palaeogeography, Palaeoclimatology, Palaeoecology 260: 122 - 148.

1138

1139 Soo, R.M., Wood, S.A., Grzymski, J.J. McDonald, I.R., Cary, S.C. (2009)

1140 Microbial biodiversity of thermophilic communities in hot mineral soils of

1141 Tramway Ridge, Mount Erebus, Antactica. Environmental Microbiology 11: 715 $1142-728$

1143

1144 Squyres, S.W., Arvidson, R.E., Ruff, S., Gellert, R., Morris, R.V., Ming, D.W.,

1145 Crumpler, L., Farmer, J.D., Des Marais, D.J., Yen, A.,McLennan, S.M., Calvin,

1146 W., Bell, J.F., Clark, B.C.,Wang, A.,McCoy, T.J., Schmidt,M.E., and de Souza,

1147 P.A. (2008) Detection of silica-rich deposion Mars. Science 320:1063-1067.

1148

1149 Stevens, T.O., McKinley, J.P. (1995) Lithoautotrophic microbial ecosystems in 1150 deep basalt aquifers. Science 270: 450-454.

1151

1152 Storrie-Lombardi, M.C., Muller, J.P., Fisk, M.R., Cousins, C., Sattler, B., 1153 Griffiths, A.D., Coates, A.J. (2009) Laser-Induced Fluorescence Emission 1154 (L.I.F.E): Searching for Mars Organics with a UV-Enhanced PanCam. 1155 Astrobiology 9, 953-964.

1156 
1157 Stroncik, N.A., Schmincke, H-U. (2002) Palagonite - a review. International

1158 Journal of Earth Science 91: 680 - 697.

1159

1160 Tanaka, K.L. (1997) Sedimentary history and mass flow structures of Chryse and 1161 Acidalia Planitiae, Mars. J. Geophys Res 102, E2, 4131-4149.

1162

1163 Tanaka, K.L., Kolb, E.J. (2001) Geologic History of the Polar Regions of Mars

1164 Based on Mars Global Surveyor Data. Icarus 154: 3-21.

1165

1166 Travis, B.J., Rosenberg, N.D. and Cuzzi, J.N. (2003) On the role of widespread

1167 subsurface convection in bringing liquid water close to Mars' surface. J.Geophys

1168 Res, 108, DOI 10.1029/2002JE001877

1169

1170 Travis, B.J. (2004) Early Mars, Hydrothermal convection plumes, and 'columns

1171 of life' [abstract 8044] Second Conference on Early Mars: Geologic, Hydrologic,

1172 and Climatic Evolution and the Implications for Life

1173

1174 Treiman, A.H., Amundsen, H.E.F., Blake, D.F., Bunch, T. (2002) Hydrothermal 1175 origin for carbonate globules in Martian meteorite ALH84001: a terrestrial 1176 analogue from Spitsbergen (Norway). Earth and Planetary Science Letters 204: $1177 \quad 323-332$. 
1178

1179 Tuffen, H., Pinkerton, H., McGarvie, D.W., Gilbert, J.S. (2002) Melting of the

1180 glacier base during a small-volume subglacial rhyolite eruption: evidence from

1181 Blahnukur, Iceland. Sedimentary Geology 149: 183-198.

1182

1183 Van Dover, C.L. (2000) The Ecology of Deep-Sea Hydrothermal Vents. Princeton

1184 Univ. Press, Princeton, NJ, 2000.

1185

1186 Varnes, E.S., Jakosky, B.M. and McCollom, T.M. (2003) Biological Potential of

1187 Martian Hydrothermal Systems. Astrobiology 3: 407 - 414.

1188

1189 Vopel, K. and Hawes, I. (2006) Photosynthetic performance of benthic microbial

1190 mats in Lake Hoare, Antarctica. Limnology and oceanography 51: 1801 - 1812.

1191

1192 Walker, J.J. and Pace, N.R. (2007) Endolithic Microbial Ecosystems. Annual

1193 Review of Microbiology 61: $331-347$.

1194

1195 Warner, N.H., Farmer, J.D. (2010) Subglacial Hydrothermal Alteration Minerals

1196 in Jökulhlaup Deposits of Southern Iceland, with Implications for Detecting Past

1197 or Present Habitable Environments on Mars. Astrobiology 10: 523 - 547.

1198 
1199 Warner, N.H., Farmer, J.D. (2008a). Importance of aeolian processes in the origin 1200 of the north polar chasmata, Mars. Icarus: $368-384$.

1201

1202 Warner, N.H., Farmer, J.D. (2008b). The origin of conical mounds at the mouth of 1203 Chasma Boreale. J. of Geophys Res. 113, doi:10.1029/2007JE003028

1204

1205 Warren, S.G., Brandt, R.E., Grenfell, T.C., and McKay, C.P. (2002) Snowball 1206 Earth: Ice thickness on the tropical ocean. J. of Geophys Res.107, 1207 doi:10.1029/2001JC001123

1208

1209 Werner, S.C. (2009) The global martian volcanic evolutionary history. Icarus 201: $1210 \quad 44-68$.

1211

1212 Wierzchos, J., Sancho, L. G and Ascaso, C. (2005) Biomineralization of 1213 endolithic microbes in rocks from the McMurdo Dry Valleys of Antarctica: 1214 implications for microbial fossil formation and their detection. Environmental 1215 Microbiology 7: 566-575.

1216

1217 Williams, K.E., McKay, C.P., Toon, O.B., Head, J.W. (2010) Do ice caves exist 1218 on Mars? Icarus 209: 358 - 368.

1219 
1220 Wilson, L., Head, J.W. (2007) Heat transfer in volcano-ice interactions on Earth. 1221 Annals of Glaciology 45: 83 - 86.

1222

1223 Wilson, L. and Head, J.W. (2002) Heat transfer and melting in subglacial basaltic 1224 volcanic eruptions: implications for volcanic deposit morphology and meltwater 1225 volumes. In Volcano - Ice Interaction on Earth and Mars, edited by J.L. Smellie 1226 \& M.G Chapman, Geological Society, London, Special Publications, 202, p.p. 5 122726.

1228

1229 Zegers, T.E., Oosthoek, J.H.P., Rossi, A.P., Blom, J.K., Schumacher, S. (2010)

1230 Melt and collapse of buried water ice: An alternative hypothesis for the formation 1231 of chaotic terrains on Mars. Earth and Planetary Science Letters 297: 496 - 504.

1232

1233 Zimbelman, D.R., Rye, R.O. and Landis, G.P. (2000) Fumaroles in ice caves on 1234 the summit of Mount Rainier-preliminary stable isotope, gas, and geochemical 1235 studies. J. Volcanol. Geotherm. Res. 97: 457-473 
Table 1. Examples of candidate volcano - ice interaction features identified on Mars, and their associated terrestrial analogue (where given). Alternative interpretations of these sites are also shown for comparison.

\begin{tabular}{|c|c|c|c|c|c|}
\hline $\begin{array}{l}\text { Region on } \\
\text { Mars }\end{array}$ & $\begin{array}{l}\text { Approximate } \\
\text { age }\end{array}$ & Description & $\begin{array}{l}\text { Terrestrial analogue cited (in } \\
\text { Iceland, unless otherwise stated) }\end{array}$ & Reference & Alternative hypotheses \\
\hline $\begin{array}{l}\text { Ascraeus Mons } \\
\text { (Tharsis) }\end{array}$ & $\begin{array}{l}\text { Mid- to Late } \\
\text { Amazonian }\end{array}$ & $\begin{array}{l}\text { Flat topped ridges typical of subglacial } \\
\text { volcanism, fan-shaped glacial deposit. }\end{array}$ & Herðubreið (Figure 2a) & Kadish et al., (2008) & $\begin{array}{l}\text { Gravity sliding and pyroclastic } \\
\text { activity (Edgett } \text { et al., 1997). }\end{array}$ \\
\hline $\begin{array}{l}\text { Chasma } \\
\text { Boreale and } \\
\text { Abalos Colles }\end{array}$ & $\begin{array}{l}\text { Amazonian }< \\
20000 \text { years }\end{array}$ & $\begin{array}{l}\text { Flat topped ridges, subglacial volcanism } \\
\text { with possible caldera lake formation, and } \\
\text { catastrophic outflow of subglacial meltwater } \\
\text { (jökulhlaup) resulting in a large water } \\
\text { incised chasm. }\end{array}$ & Gjalp 1996 subglacial eruption & $\begin{array}{l}\text { Fishbaugh \& Head } \\
(2002) ; \\
\text { Greve (2008); } \\
\text { Hovius et al., } \\
\text { (2008). }\end{array}$ & $\begin{array}{l}\text { Long term wind erosion and solar } \\
\text { ablation of ice-rich units (Warner \& } \\
\text { Farmer 2008a,b); non-uniform } \\
\text { accumulation of the north polar } \\
\text { layered deposit (Holt et al., 2010). }\end{array}$ \\
\hline $\begin{array}{l}\text { Cerberus } \\
\text { Fossae and } \\
\text { Athabasca } \\
\text { Valles }\end{array}$ & $\begin{array}{l}\text { Late } \\
\text { Amazonian } \\
<100 \mathrm{Ma}\end{array}$ & $\begin{array}{l}\text { Extensive aqueous flooding in close } \\
\text { association with large fissures and lava } \\
\text { flows, instigated by dike emplacement into } \\
\text { the cryosphere. }\end{array}$ & $\begin{array}{l}\text { Channelled Scabland in the } \\
\text { northwestern United States }\end{array}$ & Head et al. (2003) & $\begin{array}{l}\text { Release of a subsurface liquid water } \\
\text { aquifer via volcanotectonic fissures } \\
\text { (Burr } \text { et al., 2002a; Burr } \text { et al., 2002b) }\end{array}$ \\
\hline $\begin{array}{l}\text { Elysium } \\
\text { Volcanic } \\
\text { Province }\end{array}$ & $\begin{array}{l}\text { Early } \\
\text { Amazonian }\end{array}$ & $\begin{array}{l}\text { Subglacially emplaced dikes and moberg } \\
\text { ridges, possible evidence for an ice cauldron. }\end{array}$ & Gjalp and Grimsvotn & $\begin{array}{l}\text { Pedersen } \text { et al., } \\
(2010)\end{array}$ & - \\
\hline $\begin{array}{l}\text { Chryse and } \\
\text { Acidalia } \\
\text { Planitiae }\end{array}$ & $\begin{array}{l}\text { Late Hesperian } \\
\text { to Early } \\
\text { Amazonian }\end{array}$ & $\begin{array}{l}\text { Mesa-like features, drumlins, eskers, kettle } \\
\text { holes, and inverted valleys. Orbital spectral } \\
\text { data consistent with hydrous alteration of } \\
\text { volcanic materials. }\end{array}$ & $\begin{array}{l}\text { Icelandic subglacially-erupted tuyas } \\
\text { including Herðubreið and Hlodufell }\end{array}$ & $\begin{array}{l}\text { Martinez-Alonso et } \\
\text { al. (2011) }\end{array}$ & $\begin{array}{l}\text { Sedimentary deposits resulting from } \\
\text { mass flow and mass-wasting (Tanaka } \\
\text { (1997) }\end{array}$ \\
\hline $\begin{array}{l}\text { Juventae } \\
\text { Chasma and } \\
\text { Interior } \\
\text { Layered } \\
\text { Deposit } \\
\text { mounds }\end{array}$ & $\begin{array}{l}\text { Late Hesperian } \\
\text { to Amazonian }\end{array}$ & $\begin{array}{l}\text { Lava capped ridge and kettle holes, } \\
\text { interpreted as jökulhlaups following a sub- } \\
\text { ice eruption }\end{array}$ & $\begin{array}{l}\text { Gjalp } 1996 \text { subglacial eruption, } \\
\text { Skaftafjell. }\end{array}$ & $\begin{array}{l}\text { Chapman } \text { et al. } \\
\text { (2003); Chapman \& } \\
\text { Tanaka (2001) }\end{array}$ & $\begin{array}{l}\text { Evaporite deposit prior to the } \\
\text { development of the chasma, or } \\
\text { aeolian deposition of volcanic } \\
\text { sulphate aerosols (Catling } \text { et al., } \\
\text { 2006). }\end{array}$ \\
\hline $\begin{array}{l}\text { Southern polar } \\
\text { region (Dorsa } \\
\text { Argentea } \\
\text { Formation) }\end{array}$ & Hesperian & $\begin{array}{l}\text { Morphological features displaying a linear } \\
\text { trend, many of which are steep sided and flat } \\
\text { topped. Interpreted to be a subglacial } \\
\text { eruption into a previously much larger polar } \\
\text { ice cap, with channels forming possibly from } \\
\text { basal meltwater drainage. }\end{array}$ & $\begin{array}{l}\text { Drainage channels from the } \\
\text { Vatnajokull and Mydralsjokull ice } \\
\text { caps, Gjalp } 1996 \text { subglacial eruption }\end{array}$ & $\begin{array}{l}\text { Dickson \& Head } \\
\text { (2006); Ghatan \& } \\
\text { Head (2002; 2003; } \\
\text { 2004) }\end{array}$ & $\begin{array}{l}\text { Outlet channels and floodplains, } \\
\text { inverted channel deposits, and debris } \\
\text { flows (Tanaka \& Kolb 2001) }\end{array}$ \\
\hline $\begin{array}{l}\text { Ceraunius } \\
\text { Tholus \& } \\
\text { Hecates Tholus } \\
\text { (Tharsis) }\end{array}$ & Hesperian & $\begin{array}{l}\text { Volcano surrounded by valleys and } \\
\text { depositional fans. Potential for a caldera } \\
\text { lake. Interpreted to be a magmatic intrusion } \\
\text { resulting in basal melting of snowpack }\end{array}$ & $\begin{array}{l}\text { Katla - a subglacial volcano beneath } \\
\text { the Mydralsjokull ice cap, and the } \\
\text { Aniakchak caldera in Alaska } \\
\text { (Ceraunius); meltwater streams in the }\end{array}$ & $\begin{array}{l}\text { Fassett \& Head } \\
(2006 ; 2007)\end{array}$ & - \\
\hline
\end{tabular}

Mary Ann Liebert, Inc., 140 Huguenot Street, New Rochelle, NY 10801 


\begin{tabular}{|l|l|l|l|l|}
\hline & & & Antarctic Dry Valleys (Hecates). & \\
\hline $\begin{array}{l}\text { Xanthe Terra } \\
\text { (Aromatum } \\
\text { Chaos) }\end{array}$ & $\begin{array}{l}\text { Late Noachian } \\
\text { - Early } \\
\text { Amazonian }\end{array}$ & $\begin{array}{l}\text { Chaos terrain and outflow channels, } \\
\text { interpreted to be the result of cryospheric } \\
\text { disruption via the intrusion of a volcanic sill } \\
\text { and/or dikes. }\end{array}$ & $\begin{array}{l}\text { Icelandic tuyas, jökulhlaups, and } \\
\text { sandur plains }\end{array}$ & $\begin{array}{l}\text { Chapman \& Tanaka } \\
\text { (2002); Leask } \text { et al., } \\
(2006)\end{array}$ \\
& $\begin{array}{l}\text { Burial of ice sheets in a confined } \\
\text { basin resulting in basal melting, } \\
\text { eventually being released } \\
\text { catastrophically (Zegers } \text { et al., 2010); } \\
\text { dehydration of sulphates triggered by } \\
\text { geothermal heating (Montgomery \& } \\
\text { Gillespie 2005); catastrophic release } \\
\text { of groundwater from an over- } \\
\text { pressured aquifer (Carr 1979). }\end{array}$ & & \\
\hline
\end{tabular}


Table 2. Physicochemical characteristics and resident biota present within terrestrial volcano - ice related environments

\begin{tabular}{|c|c|c|c|c|}
\hline $\begin{array}{l}\text { Terrestrial } \\
\text { Environment }\end{array}$ & Location & Environment characteristics & Biota & Reference \\
\hline $\begin{array}{l}\text { Skaftá subglacial caldera } \\
\text { lake }\end{array}$ & Iceland & $\begin{array}{l}\text { Anoxic lake bottom, } 3.5-6^{\circ} \mathrm{C} \text { (whole lake), } \mathrm{pH} \\
\text { 5.22, } 6: 1 \text { mixture of glacial meltwater and } \\
\text { sulphidic geothermal fluid. }\end{array}$ & $\begin{array}{l}\text { Bacteria dominated community with no archaea so far } \\
\text { detected. Community dominated by Acetobacterium } \\
\text { species. Putative metabolic pathways include } \\
\text { homoacetogenesis }\left(\mathrm{H}_{2}+\mathrm{CO}_{2} \rightarrow \text { acetate, hydrogen }\right. \\
\text { oxidation, and sulphate reduction. }\end{array}$ & $\begin{array}{l}\text { Gaidos et al. (2009); } \\
\text { Johannesson et al. } \\
(2007)\end{array}$ \\
\hline $\begin{array}{l}\text { Grimsvotn subglacial } \\
\text { caldera lake and tephra }\end{array}$ & Iceland & $\begin{array}{l}\text { Fresh, oxygenated, } \mathrm{pH} 4.87-5.13 \text {, dominated by } \\
\text { glacial melt with acidification by volcanic } \mathrm{CO}_{2} \text {. } \\
\text { Little hydrothermal input. Coarse volcanic tephra } \\
\text { at lake bottom. }\end{array}$ & $\begin{array}{l}\text { Microorganisms adapted to growth at low temperature. } \\
\text { Distinct communities within the tephra and lake water, } \\
\text { with higher biomass in the lake tephra. Presence of } \\
\text { microbial carbon fixation (autotrophs). }\end{array}$ & Gaidos et al. (2004) \\
\hline $\begin{array}{l}\text { Mt. Erebus fumaroles, } \\
\text { Tramway Ridge }\end{array}$ & Antarctica & $\begin{array}{l}\text { Geothermally heated ice-free ground on the flank } \\
\text { of the volcano with } \mathrm{CO}_{2} \text {-rich steam fumaroles. } \\
\text { Near-neutral to acidic soil pH, temperatures } \\
\text { between } 2.5-65^{\circ} \mathrm{C} \text { (over }<0.6 \mathrm{~m} \text { distance). Low } \\
\text { total } \mathrm{C} \text { and } \mathrm{N} \text {. High in } \mathrm{Fe} \text { and Mn. }\end{array}$ & $\begin{array}{l}\text { Low sequence identity to environmental bacteria and } \\
\text { cultured isolates, suggesting the site is dominated by } \\
\text { yet-to-be described bacterial groups. Both bacterial and } \\
\text { archaea present, exhibiting high and low biodiversity } \\
\text { respectively. }\end{array}$ & Soo et al. (2009) \\
\hline $\begin{array}{l}\text { Subglacially-erupted } \\
\text { basalt (now subaerially } \\
\text { exposed) }\end{array}$ & Iceland & $\begin{array}{l}\text { High porosity }(25.8 \%) \text { basaltic-composition } \\
\text { volcaniclastic rock substrate, rich in palagonite }\end{array}$ & $\begin{array}{l}\text { Diverse community dominated by Actinobacteria, with } \\
\text { many bacteria genetically similar to those from a } \\
\text { variety of soil environments. }\end{array}$ & Kelly et al. (2010) \\
\hline $\begin{array}{l}\text { John Evans Glacier, } \\
\text { Ellesmere Island }\end{array}$ & Canada & $\begin{array}{l}\text { Base of a polythermal glacier with basal melting. } \\
\text { External mean temperature of }-14.5^{\circ} \mathrm{C} \text {. }\end{array}$ & $\begin{array}{l}\text { Psycrophillic organisms including aerobic } \\
\text { chemoheterotrophs, anaerobic nitrate reducers, } \\
\text { sulphate reducers, and methanogens. }\end{array}$ & $\begin{array}{l}\text { Skidmore } \text { et al. } \\
(2000)\end{array}$ \\
\hline
\end{tabular}



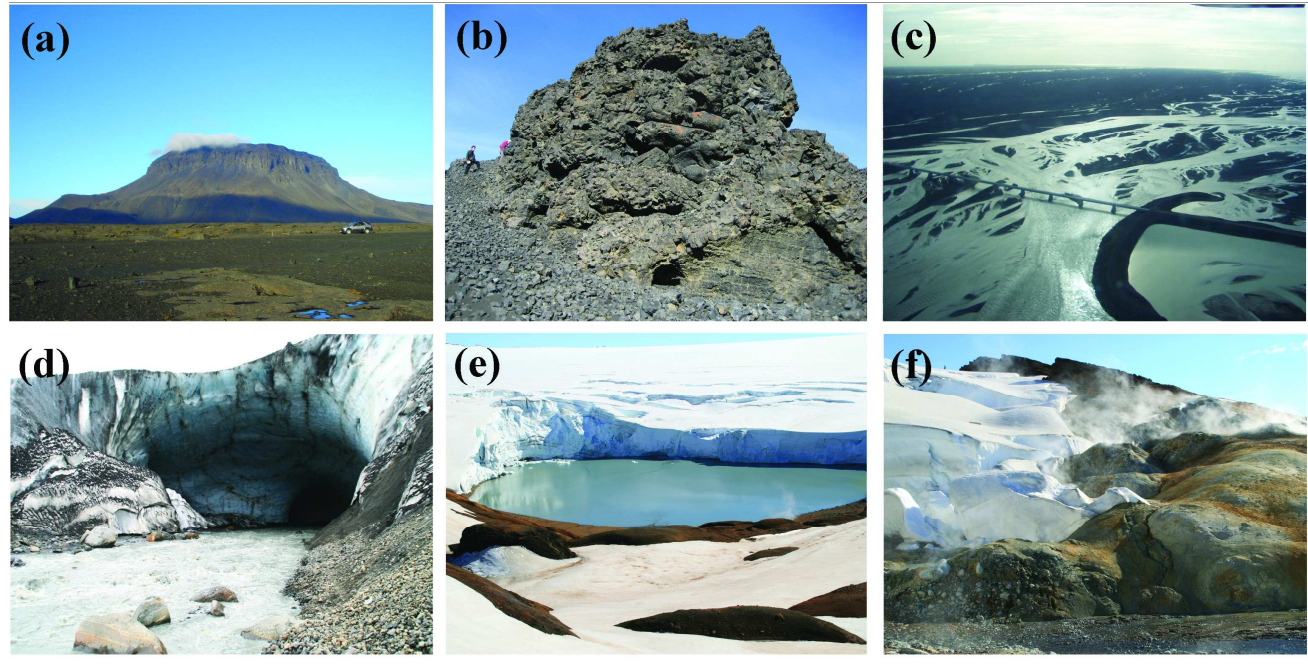

\section{(e)}
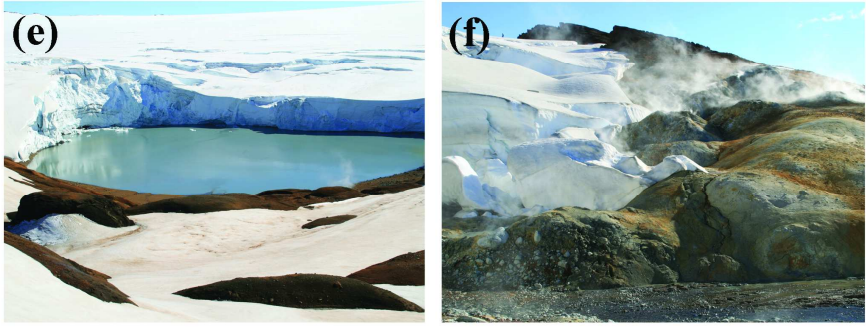

FIG. 1. Icelandic examples of subglacial volcanic products and environments. a) Tuya (Herðubreið) with car for scale; b) Pillow mound, in central Iceland (people on left for scale); c) Sandur subglacial outwash plain in south Iceland (road bridge for scale); d) Glacier cave at Kverkfjöll; e) Subaerial glacial meltwater lake ( $500 \mathrm{~m}$ across) above the subglacial volcano Kverkfjöll; f) fumaroles and hot springs interacting with the glacier surface at Kverkfjöll volcano. $159 \times 80 \mathrm{~mm}(488 \times 488$ DPI $)$ 
1

2

3

4

5

6

7

8

9

10

11

12

13

14

15

16

17

18

19

20

21

22

23

24

25

26

27

28

29

30

31

32

33

34

35

36

37

38

39

40

41

42

43

44

45

46

47

48

49

50

51

52

53

54

55

56

57

58

59

60
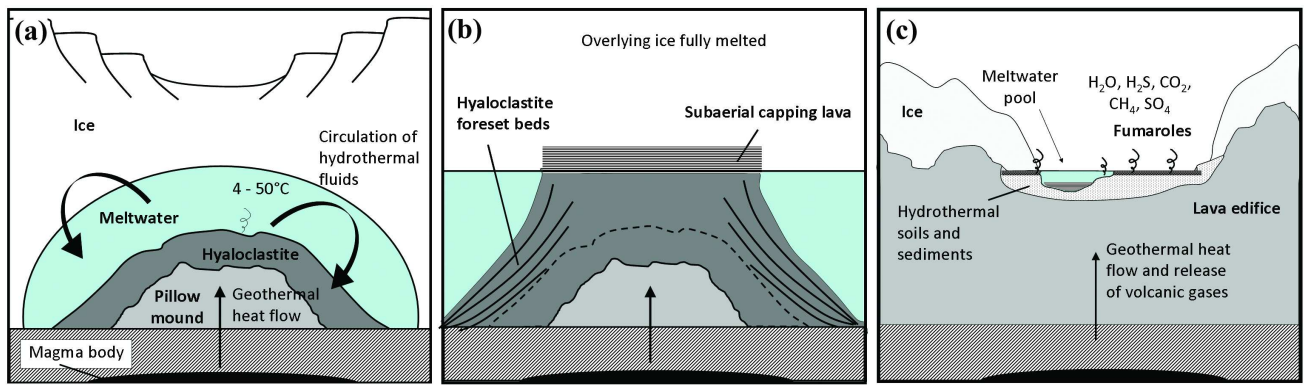

FIG. 2. Simplified diagram showing the processes of volcano - ice interaction: a) initial subglacial eruption into overlying ice, creating a meltwater lens and ice cauldron at the glacier surface; b) emergent eruption, whereby sustained volcanic activity eventually melts through the ice, resulting in subaerial capping lavas when the edifice becomes higher than the waterline, forming a tuya morphology; c) subaerial hot springs and fumaroles at the glacier surface, sourced by surface glacial meltwater and underlying geothermal activity. $159 \times 46 \mathrm{~mm}(488 \times 488 \mathrm{DPI})$ 
FIG. 3. Map of localities given in Table 1 (Image credit: National Geographic Society, MOLA Science Team, MSS, JPL, NASA). $159 \times 99 \mathrm{~mm}(488 \times 488 \mathrm{DPI})$ 


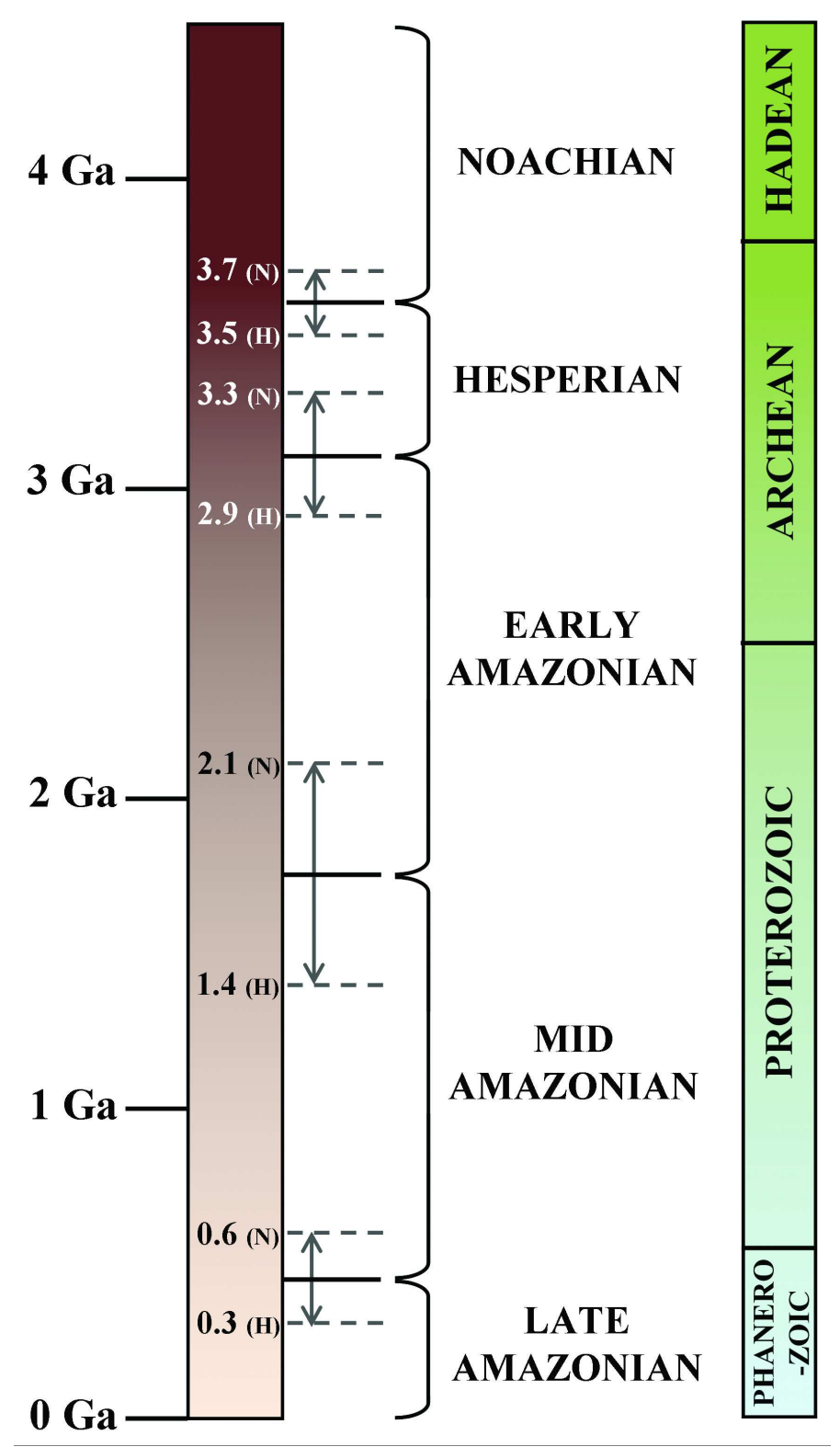

FIG. 4. Geological time scales for Mars (left) and the corresponding divisions for Earth (right). Boundary variations for both the Neukum ('N') or Hartmann ('H') chronology models (Hartmann \& Neukum 2001) are shown. $85 \times 149 \mathrm{~mm}(522 \times 522 \mathrm{DPI})$ 

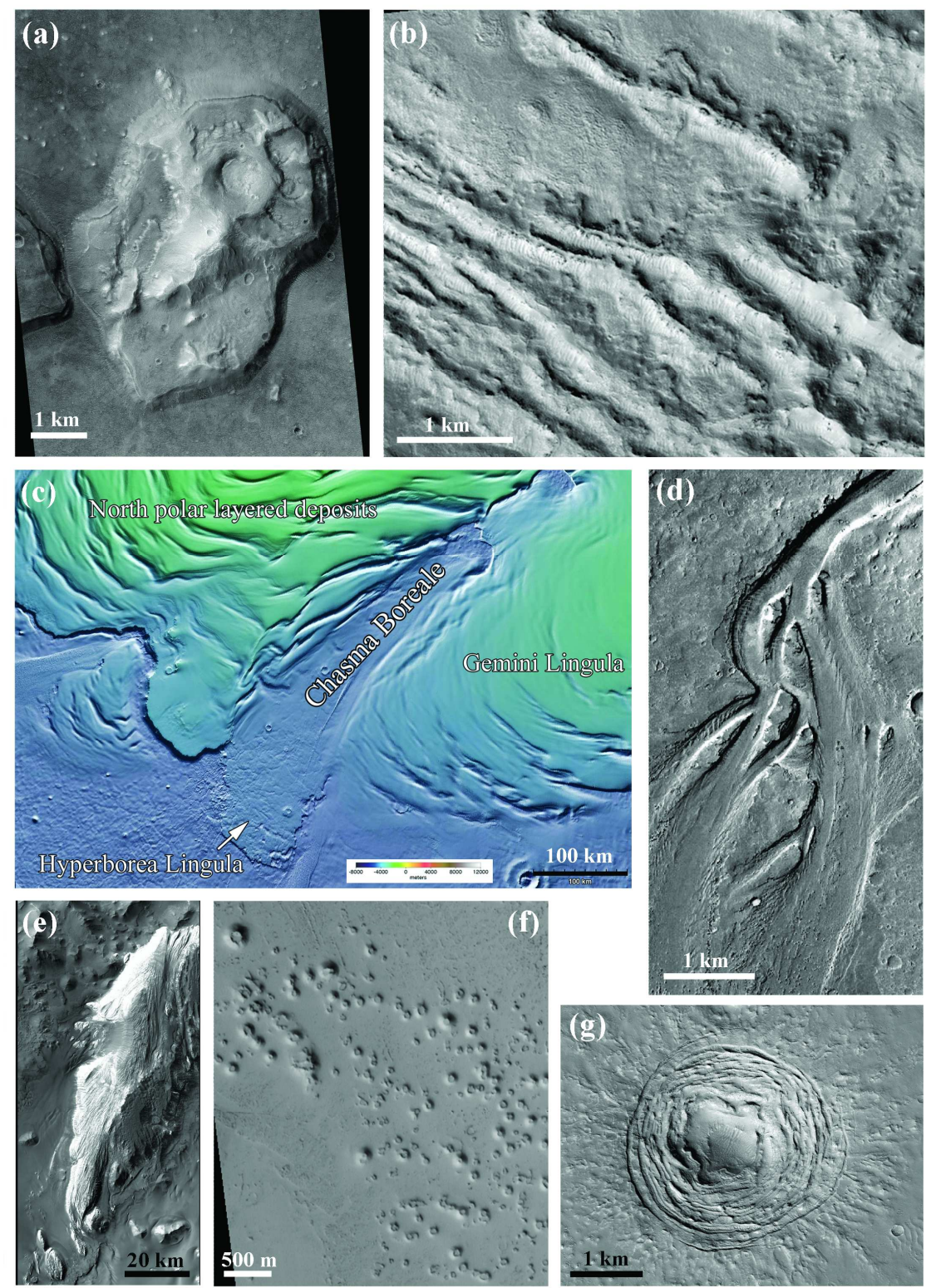

(i)

FIG. 5. Examples of putative glaciovolcanic features on Mars as described in the text and given in Table 1. a) Mesa at Acidalia Planitia interpreted as a possible tuya (Martinez-Alonso et al., 2011; HiRISE image PSP_009497_2210_RED) ; b) putative subglacially erupted dykes near the Elysium Volcanic Province (Pedersen et al., 2010; HiRISE image PSP_006591_2165); c) Chasma Boreale (Fishbaugh \& Head 2002; MOLA shaded relief map overlain on a THEMIS IR day 100 m mosaic); d) large drainage channels in the Athabasca Valles (Burr et al., 2002; MOC image M2101914); e) Interior Layered Deposit in Juventae Chasma (Chapman 2003; MRO CTX image B18_016712_1762_XN_03S061W); f) pseudocraters or "rootless cones" north of the Cerberus plains (Fagents et al., 2002; MOC image M08/01962); g) ice-cauldron morphology at Galaxias Fossae (Levy et al., 2010; HiRISE image PSP_005813_2150). $160 \times 223 \mathrm{~mm}(349 \times 349 \mathrm{DPI})$ 

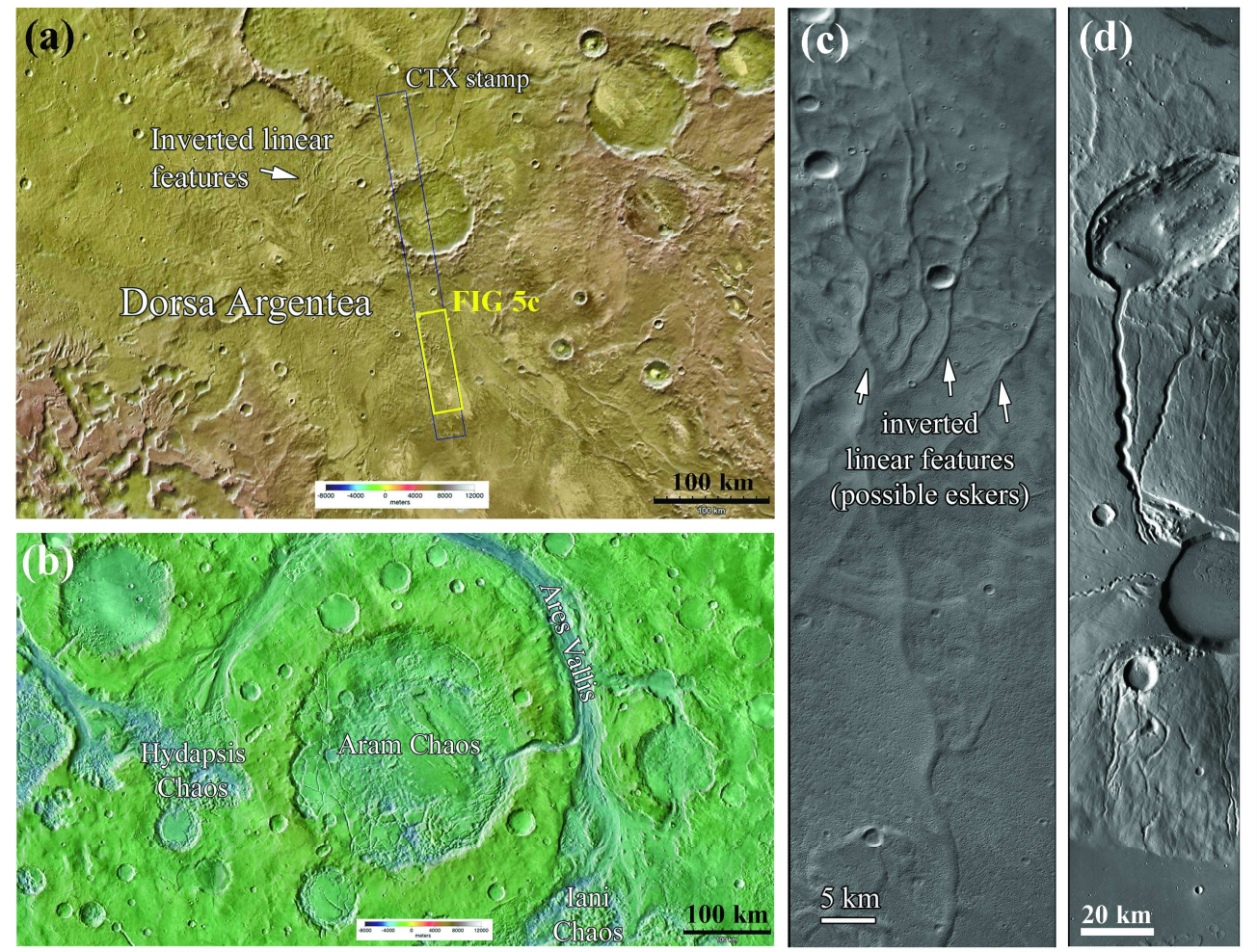

FIG. 6. More examples of putative glaciovolcanic features on Mars as described in the text and given in Table 1. a) broad view of the Dorsa Argentea Formation with numerous inverted linear features, shown in more detail in Figure 5c (Ghatan \& Head 2004; (MOLA shaded relief map overlain on a THEMIS IR day $100 \mathrm{~m}$ mosaic); b) Chaos terrain and drainage channels at Xanthe Terra (Chapman \& Tanaka 2002; MOLA shaded relief map overlain on a THEMIS IR day $100 \mathrm{~m}$ mosaic); c) Inverted linear features interpreted as eskers (Ghatan \& Head 2004, MRO CTX image

P13_006282_1046_XN_75S043W); d) volcano Ceraunius Tholes showing evidence of floodwater originating at the caldera rim (Fassett \& Head 2007; MRO CTX image B04_011399_2045_XN_24N097W). $159 \times 124 \mathrm{~mm}(488 \times 488 \mathrm{DPI})$ 